Provided for non-commercial research and educational use only. Not for reproduction or distribution or commercial use.

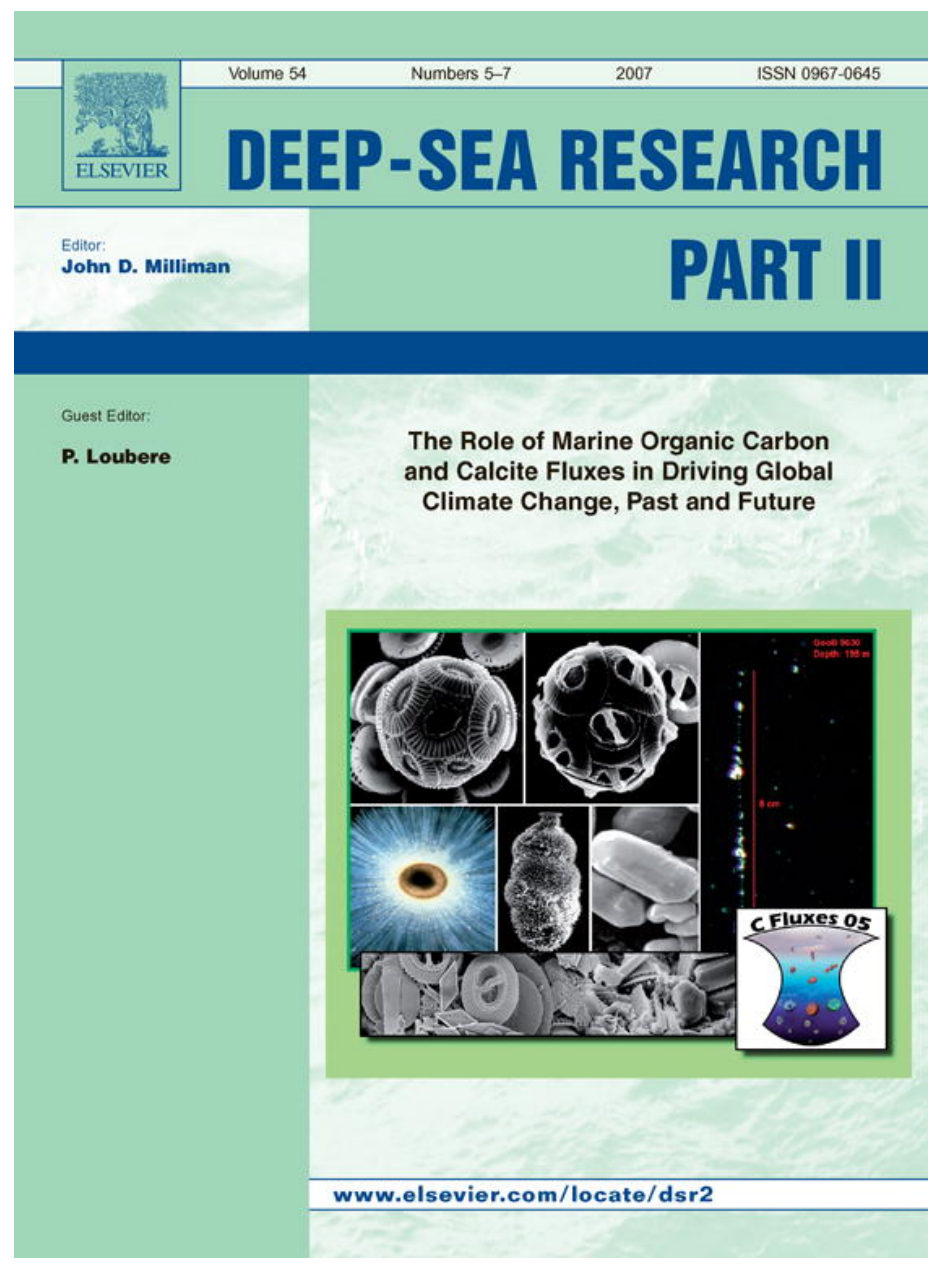

This article was originally published in a journal published by Elsevier, and the attached copy is provided by Elsevier for the author's benefit and for the benefit of the author's institution, for non-commercial research and educational use including without limitation use in instruction at your institution, sending it to specific colleagues that you know, and providing a copy to your institution's administrator.

All other uses, reproduction and distribution, including without limitation commercial reprints, selling or licensing copies or access,

or posting on open internet sites, your personal or institution's website or repository, are prohibited. For exceptions, permission may be sought for such use through Elsevier's permissions site at: 


\title{
Factors influencing the sinking of POC and the efficiency of the biological carbon pump
}

\author{
Christina L. De La Rocha*, Uta Passow \\ Alfred Wegener Institute for Polar and Marine Research, Postfach 12 0161, 27515 Bremerhaven, Germany
}

Accepted 8 January 2007

Available online 7 March 2007

\begin{abstract}
By altering the number, size, and density of particles in the ocean, the activities of different phytoplankton, zooplankton, and microbial species control the formation, degradation, fragmentation, and repackaging of rapidly sinking aggregates of particulate organic carbon (POC) and are responsible for much of the variation in the efficiency of the biological carbon pump. A more systematic understanding of these processes will allow the biological pump to be included in global models as more than an empirically-determined decline in POC concentrations with depth that may not adequately represent past or future conditions. Although progress has been made on this front, key areas needing work are the amount of POC flux associated with appendicularians, the mechanisms by which coccoliths and coccolithophorid POC reach depth, and the impact of polymers such as TEP on the porosity of aggregates. In addition, an understanding of the interaction between biological and physical aspects of the pump, such as aggregate loading with suspended mineral particles, is also important for understanding the transmission of biogenic materials through the meso- and bathypelagic realms. Data suggest that variable biogenic silica to POC production ratios in various ocean regions are responsible for the poor correlation observed between silica and POC in deep sediment traps, and that high concentrations of suspended coccoliths in deep waters may be responsible for the homogeneous calcium carbonate to POC ratios observed in these same traps. Sedimentation of foraminiferal calcite does not appear to be as tightly correlated to POC flux as coccolith sedimentation. Suspended calcium carbonate particles, scavenged by sinking organic aggregates, have been observed to both fragment and increase the density of these aggregates. Analysis of the data suggests that scavenging of minerals by aggregates decreases the porosity of the aggregates and may increase their sinking velocities by hundreds of times.
\end{abstract}

(C) 2007 Elsevier Ltd. All rights reserved.

Keywords: Biological pump; Aggregates; Mineral ballast; Sinking velocities; POC; Export efficiency

\section{Introduction}

Important to our understanding of marine biogeochemistry and glacial-interglacial climate

\footnotetext{
*Corresponding author. Tel.: + 4947148311040 ; fax: + 4947148311923 .

E-mail addresses: crocha@awi-bremerhaven.de (C.L. De La Rocha), upassow@awi-bremerhaven.de (U. Passow).
}

cycles is the transfer to depth of particulate organic carbon (POC) via the biological pump. The "efficiency" of the biological pump, looked at as the fraction of primary production exported from the euphotic zone, and as the fraction of this export production that reaches the deep sea, is controlled by numerous, often interrelated, processes, including the aggregation and disaggregation of organicrich aggregates, microbial activities, grazing and 
fecal pellet production by zooplankton, and interaction between POC aggregates and suspended "ballast" minerals (Fowler and Knauer, 1986; Alldredge and Silver, 1988; Banse, 1990; Jackson and Burd, 1998; Ducklow, 2000; Antia et al., 2001; Armstrong et al., 2002; François et al., 2002; Klaas and Archer, 2002; Passow, 2002; Simon et al., 2002; Thornton, 2002; Turner, 2002; Volkman and Tanoue, 2002; De La Rocha, 2003). Although there is extensive literature on most of the processes known to affect the efficiency of the transport of POC to depth, most of these processes are not quantitatively understood. Thus, although progress is being made towards the development of effective models of the biological pump (Kriest and Evans, 1999; Dadou et al., 2001; Doney et al., 2002; Kriest, 2002; Stemmann et al., 2004a,b), the biological pump in ocean models is still predominantly described by the "Martin curve" and its relatives, an empirically determined exponential decline in POC concentrations with depth below the euphotic zone (Suess, 1980; Martin et al., 1987; Lutz et al., 2002; Andersson et al., 2004). In addition, the complexity of the biological pump is largely ignored in geochemical considerations of the particulate inorganic carbon (PIC): POC rain ratio and the links between the biological pump, atmospheric $\mathrm{CO}_{2}$, and climate cycles in the past (Sigman and Boyle, 2000).

There are many recent and/or classic reviews of different aspects of the biological pump from the formation and properties of aggregates (Fowler and Knauer, 1986; Alldredge and Silver, 1988; Jackson and Burd, 1998; Passow, 2002; Simon et al., 2002; Thornton, 2002; Volkman and Tanoue, 2002; Verdugo et al., 2004), to the flux of POC (Honjo, 1996; Jahnke, 1996; Buesseler, 1998; Antia et al., 2001), the suspension, sinking, and degradation of particles (Smayda, 1970; Banse, 1990), the role of zooplankton in the particle flux (Turner, 2002), and the impact of the biological pump on marine geochemistry (De La Rocha, 2003). This manuscript thus will not cover any particular aspect of the biological pump in the great detail required of a review. Instead its first aim is to provide a simple overview, for those more deeply versed with the past climatic impact of the biological pump than the complexities of its workings, of the processes that control the amount of primary production, exported from the euphotic zone, that reaches the deep sea and its sediments. Secondly, while the importance of aggregates and transparent exopoly- mer particles (TEPs) to the sinking of POC has been appreciated for 15-20 years, the role of mineral "ballast" has recently come to the fore as a possible major control over POC flux (Armstrong et al., 2002; François et al., 2002; Klaas and Archer, 2002). Given the current interest in this topic, this manuscript takes a detailed look at the potential impact of minerals on the character and sinking velocity of organic-rich aggregates.

\section{The means and forms by which POC sinks to the deep sea}

\subsection{The effectiveness of the biological pump}

The biological pump is a set of processes largely viewed as a powerful means of transporting POC to depth. Its removal of fixed carbon from surface waters maintains the gradient in dissolved inorganic carbon that held Holocene, pre-industrial atmospheric $\mathrm{CO}_{2}$ concentrations at $280 \mu \mathrm{atm}$ instead of the $415 \mu \mathrm{atm}$ expected from the total dissolved inorganic carbon content of the ocean (Broecker, 1982). Variability in the efficiency of the biological pump also has played a role in the past glacial-interglacial cycling of atmospheric $\mathrm{CO}_{2}$ between 190 and $280 \mu \mathrm{atm}$ (Kohfeld et al., 2005).

Despite these feats, the biological pump is inefficient at getting POC into the deep sea and sediments. Most of the net $50 \mathrm{PgC}$ fixed into phytoplankton biomass each year (Field et al., 1998) is remineralized in the upper few hundred meters of the ocean (Bishop et al., 1978; Suess, 1980; Martin et al., 1987). Only somewhere between 5\% and 25\% (Martin et al., 1987; Buesseler, 1998; Schlitzer, 2000) of net primary production is exported from the euphotic zone, and only about $1-3 \%$ reaches the deep sea and sediments.

Although, as a whole, the biological pump is inefficient at transporting fixed carbon to depth, there is considerable regional and temporal variability in the fraction of net primary production that is exported to depth. In central gyres, only $1-10 \%$ of net primary production is exported from the euphotic zone (Buesseler, 1998; Neuer et al., 2002), while anywhere between $30 \%$ and $100 \%$ of the net primary production may be exported from polar regions (Buesseler, 1998). Likewise, the vertical flux of POC through deeper depths is higher in productive continental margin regions than in central gyres (Jahnke, 1996). 
This variability is predominantly biological in origin, stemming from differences in phytoplankton, zooplankton, and microbial communities and food-web structures (Legendre and Rivkin, 2002) at various times and places. In addition, a greater supply of suspended minerals on continental margins than in the open seas may make a contribution to the increased efficiency of the biological pump at the margins. What these differences in the "biological" and "mineral" components of the biological pump mean is that POC within the ocean is not a single amorphous category of material of undefined behavior and uniform propensity to sink. It is instead many different organisms and their product, which are packaged and repackaged into particles of various shapes, sizes, physical and chemical compositions, characteristics, sinking velocities, and degradability (Fowler and Knauer, 1986; Alldredge and Silver, 1988; Silver and Gowing, 1991). The interaction of POC with mineral particles may further alter its size, character, and sinking velocity (Armstrong et al., 2002; François et al., 2002; Klaas and Archer, 2002; Passow, 2004; Passow and De La Rocha, 2006).

\subsection{Sinking of $P O C$ in the form of aggregates}

The amount of the POC fluxing through any given depth depends on the balance between the sinking velocities ( $W$ in units of $\mathrm{md}^{-1}$ ) of the organic particles and the rates of their decomposition ( $D$ in mass mass ${ }^{-1} \mathrm{~d}^{-1}$ ), for example, as in (Banse, 1990)

$\frac{\mathrm{d} C_{z}}{\mathrm{~d} z}=-\frac{D}{W} C_{z}$,

where $C_{z}$ is the POC flux reaching depth $z$. To take the broad view, only three things influence the total amount of POC that is pumped to depth: the flux generated in the euphotic zone, the velocity with which it sinks, and the rate at which it decomposes or is grazed.

One key control of the sinking velocity of POC in the ocean is the size of the sinking material. The POC that sinks out of the euphotic zone does so, not as small, individual phytoplankton, which generally sink less than $2 \mathrm{md}^{-1}$ (Fowler and Knauer, 1986), but as components of large particles (McCave, 1975; Suess, 1980; Billett et al., 1983) that reach the deep within days to weeks (Billett et al., 1983; Asper et al., 1992) owing to sinking velocities that range one order of magnitude up from $50 \mathrm{~m} \mathrm{~d}^{-1}$
(Shanks and Trent, 1980; Billett et al., 1983; Alldredge and Gotschalk, 1988; Asper and Smith, 2003).

Large composite particles with diameters greater than $0.5 \mathrm{~mm}$ are known collectively as "marine snow" (Alldredge and Silver, 1988) and consist of the discarded feeding structures of appendicularians, planktonic foraminifera, and pteropods (Alldredge and Silver, 1988; Hansen et al., 1996; Gorsky et al., 1999; Alldredge, 2005) that may collect additional particles as they sink, and aggregates formed by the physical coagulation of smaller particles (McCave, 1984; Jackson and Burd, 1998). The presence of TEP, which act as the matrix of aggregates and as "glue" towards most types of particles (Passow, 2002), is a prerequisite for the formation of aggregates through coagulation (Logan et al., 1995). The rate of aggregate formation through coagulation furthermore depends on the size and concentration of particles (e.g., diatoms, feces, and detritus) in the water (Hill, 1992; Jackson, 1990; Logan et al., 1995). Some efforts have been made to incorporate these processes and their impact on POC flux into biogeochemical models (e.g., Kriest and Evans, 1999; Kriest, 2002).

POC may also be packaged into fecal pellets (Bishop et al., 1978, 1980; Honjo and Roman, 1978) that may be large and dense enough to sink rapidly on their own but also may become incorporated into aggregates. In addition, whole organisms, such as protozoans, amphipods, and pteropods, may sink rapidly in association with marine snow, or, if they have heavy tests, like radiolarians and foraminifera, they may sink individually after cell death (Silver and Gowing, 1991). By definition, dissolved organic carbon (DOC) does not sink, but may assemble into colloids and particles that aggregate and then sink (Alldredge et al., 1993; Kepkay, 1994; Chin et al., 1998; Verdugo et al., 2004). Sinking aggregates also may carry a significant amount of DOC down with them in their pore water (Noji et al., 1999; Antia, 2005), as a third of the total carbon in aggregates may be interstitial DOC (Alldredge, 2000).

\subsection{Controls on the sinking velocity of aggregates}

Since the sinking velocity of aggregates is critical to the proportion of primary production reaching the deep sea, it is useful to be able to describe, mathematically, how particles sink. According to Stokes' Law, sinking velocities $(W)$ of spherical particles at low Reynold's numbers decrease with 
the porosity and increase with the density and the square of the radius ( $r$ ) of the particles (e.g., Johnson et al., 1996):

$W=(1-P) \frac{2}{9} \frac{g r^{2}(\Delta \rho)}{\mu}$,

where $(1-P)$ is fraction of the particle that is solid material, $g$ the acceleration due to gravity, $\mu$ the dynamic viscosity of seawater, and $\Delta \rho$ the density difference between the solid material of the particle and seawater (i.e., $\rho_{\mathrm{sm}}-\rho_{\mathrm{sw}}$ ). The only terms to vary in the ocean are the dynamic viscosity of seawater, the porosity and the radius of the particle, and the particle density relative to seawater. Although $\mu$ is strongly temperature dependent, a drop in seawater temperature from 20 to $0{ }^{\circ} \mathrm{C}$ would only diminish sinking velocities by $43 \%$; thus sinking velocities of particles in the ocean (and the deep ocean especially) should largely vary as a factor of $(1-P)$ $r^{2}(\Delta \rho)$. If the greater than $99 \%$ porosity observed for aggregates in surface waters (Alldredge and Gotschalk, 1988) holds through the meso- and bathypelagic zones, sinking velocities should then largely only vary with $r^{2}(\Delta \rho)$.

Predictions of sinking velocities of aggregates from their size and density are complicated by the fact that most marine aggregates are not spherical and exhibit fractal geometries (Logan and Wilkinson, 1990; Jiang and Logan, 1991; Li and Logan, 1995). The increased drag upon them due to their shape slows their sinking relative to spheres of equivalent mass and density (Alldredge and Gotschalk, 1988). The potential for increased flow through them due to their fractal geometry relative to non-fractal particles with the same average porosity, in contrast, reduces the drag upon them relative to non-fractal particles (Johnson et al., 1996), presuming that polymers such as TEP do not clog up the pore space of the aggregate.

Although the fractal geometry and variety of shapes of sinking particles in the sea obscure the relationship between particle sinking velocities and their density, the general tenet of Stokes' law, that sinking velocities are a function of particle size and density relative to seawater, holds. Empirical estimates of the sinking velocities of fractal organic aggregates in the upper ocean, for example, are related to $d$, the aggregate diameter (e.g. $W=$ $50 d^{0.26}$ from Alldredge and Gotschalk, 1988), and marine-snow-sized aggregates settle tens of times more rapidly than individual phytoplankton cells (Smayda, 1970; Alldredge and Gotschalk, 1988;
Jackson and Burd, 1998). So although Stokes' law does not perfectly describe the sinking of fractal organic aggregates in the sea, its separation of the different physical factors influencing sinking rates means that it is useful for considering the different impacts of size, density, and porosity on sinking velocities.

Particle size, density, and porosity being the direct controls of the sinking velocity of organic particles in the ocean means that there are numerous indirect controls on the sinking velocities of organic aggregates. Aggregation, disaggregation, organic matter degradation, fragmentation, grazing, and fecal pellet production by zooplankton, mineral scavenging, and other processes change aggregate size, composition, and character. As a result, over the course of its residence in the water column, POC shifts through a spectrum of sizes and sinking velocities, from suspended to sinking more than $500 \mathrm{~m}$ per day (Jackson et al., 1997; Berelson, 2002; Turner, 2002).

Exopolymers such as TEP, despite adding lowdensity mass $\left(0.70-0.84 \mathrm{~g} \mathrm{~cm}^{-3}\right.$; Azetsu-Scott and Passow, 2004) to aggregates, generally enhance sinking velocities by promoting the formation of larger, faster-sinking aggregates. TEP also might clog up the pore space within the aggregates, diminishing the drag experienced by a sinking aggregate. This process has been invoked as a possible reason for the observed variability in the sinking velocity versus size of aggregates (Ploug et al., 2002).

Eq. (2) suggests that such lowering the porosity of an aggregate could have a great impact on its sinking velocity. A decline in porosity from 0.997 , a typical calculated value for marine snow, to a value like 0.8 or 0.5 increases the predicted Stokes' sinking velocity for a spherical particle by a factor of 70 or 170, respectively. Work directly addressing the impact of porosity and fluid flow through fractal aggregates on their sinking velocity is needed to help quantify the importance of natural variations in aggregate porosity to POC flux.

The feeding and swimming of zooplankton are processes that affect the residence time of particulate organic matter in the upper ocean and the flux of POC to depth. Feeding of zooplankton on suspended phytoplankton cells results in the production of fecal pellets. The type of zooplankton involved will determine in large part the size and sinking velocity of the pellet produced (Turner, 2002) and thus whether or not grazing serves to 
increase the sinking flux of POC. Certain types of zooplankton (e.g., copepods and euphausiids but not salps) also may actively feed on aggregates (Bochdansky and Herndl, 1992; Green and Dagg, 1997; Dilling et al., 1998; Schnetzer and Steinberg, 2002; Kosky et al., 2005), potentially sensing them from the chemical plumes they emit (Kiørboe and Thygesen, 2001) and reducing the number of marine-snow-sized particles with large sinking velocites in the surface ocean. Zooplankton also may fragment aggregates while they swim, breaking them up into numerous smaller particles with lower sinking velocities (Dilling and Alldredge, 2000; Goldthwait et al., 2004). Further, such fragmentation of an aggregate releases DOC that had been hitherto contained within the aggregate (Goldthwait et al., 2005) and may have otherwise sunk with the aggregate into deeper waters (Alldredge, 2000).

These are processes that are quantifiable (see Dilling and Alldredge, 2000) and could be included into models. Simple calculations, for example, have been used to show that fragmentation of aggregates by swimming euphausiids could explain observed diel variation in marine snow abundance in the Santa Barbara Basin (Dilling and Alldredge, 2000). As in Dilling and Alldredge (2000), data on the distribution of the zooplankton and estimates of the amount of the time they spent each day swimming at given depths can be coupled with estimates that exist for the volume of water disturbed by euphausiids as they swim (measurements for other types of zooplankton need to be made), marine snow abundance (as measured via camera, e.g., Gorsky et al., 2003), and the probability that an encountered aggregate of marine snow will fragment into 2, 3, or more particles (Dilling and Alldredge, 2000; Goldthwait et al., 2004).

Feeding of zooplankton on fecal pellets is another way in which zooplankton influence POC sinking velocities and, in these cases, increase the residence time of POC in the water column (Noji et al., 1991). Direct ingestion of fecal pellets (coprophagy) has the effect of removing large, fast-sinking particles from the water column before they have a chance to sink to great depths. Zooplankton also might fragment fecal pellets during the course of feeding upon them, breaking them into smaller, more slowly sinking particles. Removal and consumption of the peritrophic membrane that surrounds fecal pellets (Lampitt et al., 1991) also results in the dispersal of fecal pellet material (as smaller, more numerous, more slowly sinking particles) into the water column.

It also has been proposed that incorporation of minerals into aggregates may significantly increase the sinking velocities of aggregates (Honjo, 1982; Armstrong et al., 2002; François et al., 2002; Klaas and Archer, 2002). The relationship between the mineral content of an organic aggregate and its sinking velocity is not straightforward, as minerals add density to aggregates but also decrease their size (Hamm, 2002) and fragment them into smaller particles (Passow and De La Rocha, 2006). The result are non-linear changes of sinking velocity with mineral addition (Hamm, 2002) that may account for the observation that in the deep-sea, mineral contents do not appear to systematically influence sinking velocities of marine-snow-sized particles (Berelson, 2002).

Some observations exist of the uptake of minerals by aggregates (Honjo, 1982; Hamm, 2002; Passow and De La Rocha, 2006) and the impact of minerals on sinking velocities may be at least roughly calculated (see calculations later in paper). Before this process can be included in models, however, the rate and probability of incorporation of minerals into organic aggregates need to be better quantified, as does the impact of the minerals on aggregate characteristics (density, porosity, etc.). Therefore information is needed about the concentration of sinking and suspended particles of calcium carbonate, silica, and clay minerals in ocean waters below the euphotic zone. The ratio of the silica to calcium carbonate fluxes into deep sediment traps increases with depth. And the relationship between mineral and organic fluxes (Bishop et al., 1978; Armstrong et al., 2002; François et al., 2002; Klaas and Archer, 2002) suggests that there may be a significant supply of scavengeable minerals (e.g., coccoliths, whole and intact foraminifera and pelagic molluses, whole and intact diatoms and radiolarians, and clay minerals) in deeper waters.

\subsection{Degradation of particulate organic matter}

The degradation of particulate organic matter is carried by zooplankton and bacteria and has a twofold impact on the biological pump. First, grazing and decomposition by zooplankton and bacteria, which solubulize POC to DOC, oxidize it to $\mathrm{CO}_{2}$, or assimilate it into food webs, remove most of the POC from the biological pump in the upper water column (Bishop et al., 1978; Suess, 1980; Martin 
et al., 1987; Buesseler, 1998; Schlitzer, 2000). And, second, there is a marked increase in particle sinking velocities with depth in the ocean, and this might be tied to the loss of organic carbon from these particles during sinking, the transmission of only fast-sinking particles to the deep sea, or it may be a side effect of the successive repackaging of sinking material by deep-dwelling heterotrophic organisms (Berelson, 2002).

One key question about the biological pump concerns what portion of the $97-99 \%$ of net primary production that is oxidized back to $\mathrm{CO}_{2}$ instead of being preserved in deep-sea sediments is cycled through the zooplankton versus the bacteria. Estimates of the portion of net primary production grazed, ingested, and respired by micro- and mesozooplankton are high, often on the order of $30-70 \%$ and $20-35 \%$ of net primary production apiece (e.g., Calbet and Landry, 2004; HernándezLeón and Ikeda, 2005). These estimates, however, must be balanced against claims that bacteria do the bulk of the respiration within the ocean (Rivkin and Legendre, 2001). Indeed, when estimated respiration rates of microbes (including phytoplankton) are added to those of zooplankton, the result is often in excess of gross primary production, unless one assumes that DOC excretion by phytoplankton is a sizeable and overlooked contribution to gross primary production (del Giorgio and Duarte, 2002). It is clear at this point in time that while annual estimates of marine respiration (including that of phytoplankton) of $41-77 \mathrm{PgCy}^{-1}$ (del Giorgio and Duarte, 2002) may be reasonable, it is currently unknown what portion of this is carried out by zooplankton and what portion is carried out by bacteria.

One thing there is a current estimate of, however, is the magnitude of bacterial assimilation of carbon relative to net primary production. Based on a suite of studies of bacterial production measured by such assays as the incorporation of tritiated thymidine into bacterial biomass, it appears that the net assimilation of organic carbon by bacteria each year is equivalent to $15 \%$ of the carbon fixed through photosynthesis (Ducklow, 2000). Although much of this assimilated organic carbon comes from the low-molecular-weight DOC pool, particle-associated microbes may rapidly solubulize organic matter from particles (Cho and Azam, 1988; Karl et al., 1988; Smith et al., 1992; Sempéré et al., 2000).

Microbial rates of particle decomposition depend on both physical parameters (temperature and pressure) and biological ones (e.g., particle composition and character, ectoenzyme activities, and the composition, abundance, and activity of microbial communities). For example, hydrolysis rates of complex polysaccharides vary a great deal both spatially and temporally (Arnosti, 1996; Arnosti et al., 2005) as do cell-specific enzyme activities and the suite of enzyme activities expressed by bacterial assemblages (Martinez et al., 1996), implying variability in the ability of microbial populations to degrade POC. It is also generally accepted that particle-attached bacteria, such as those present on aggregates, have markedly higher cell-specific hydrolytic enzyme activities, but not elevated demands for carbon, relative to the free-living bacteria present in the water column (Cho and Azam, 1988; Karl et al., 1988; Smith et al., 1992). Thus, while it is particle-associated microbes that convert POC to DOC, it is free-living microbes that are oxidizing the organic carbon, now in the form of DOC (Kiørboe and Jackson, 2001; Thor et al., 2003).

\subsection{Distribution of marine snow in the water column}

Together with the sinking velocities they impact, coagulation, fragmentation, consumption, and decomposition control the standing stock of aggregates in the water column at any given depth. Advection of water masses may also transport aggregates laterally significant distances from their point of origin (Gorsky et al., 2003). Cameras lowered from ships or mounted on ROVs provide a wealth of data concerning the abundance, size, and distribution of large particles in the water column (Honjo et al., 1984; MacIntyre et al., 1995; Pilskaln et al., 1998; Graham et al., 2000; Asper and Smith, 2003; Gorsky et al., 2003). Fig. 1 shows examples of the mean equivalent spherical diameter of particles $>0.15 \mathrm{~mm}$ against depth in various ocean regions.

The greatest number and overall volume of organic aggregates occur in surface waters (e.g. Fig. 1) especially in productive regimes. In areas such as the Santa Barbara Basin or the Southern Ocean, aggregate numbers may easily reach $50-80 \mathrm{~L}^{-1}$, and average aggregate volume and total aggregate volume may reach $0.5-1 \mathrm{~mm}^{-3}$, and $10-60 \mathrm{~mm}^{-3} \mathrm{~L}^{-1}$, respectively (MacIntyre et al., 1995; Graham et al., 2000). In parallel to the rapid decline in POC (Suess, 1980; Martin et al., 1987) and calcium carbonate concentrations (Schiebel, 2002) below the euphotic zone, the number per liter 

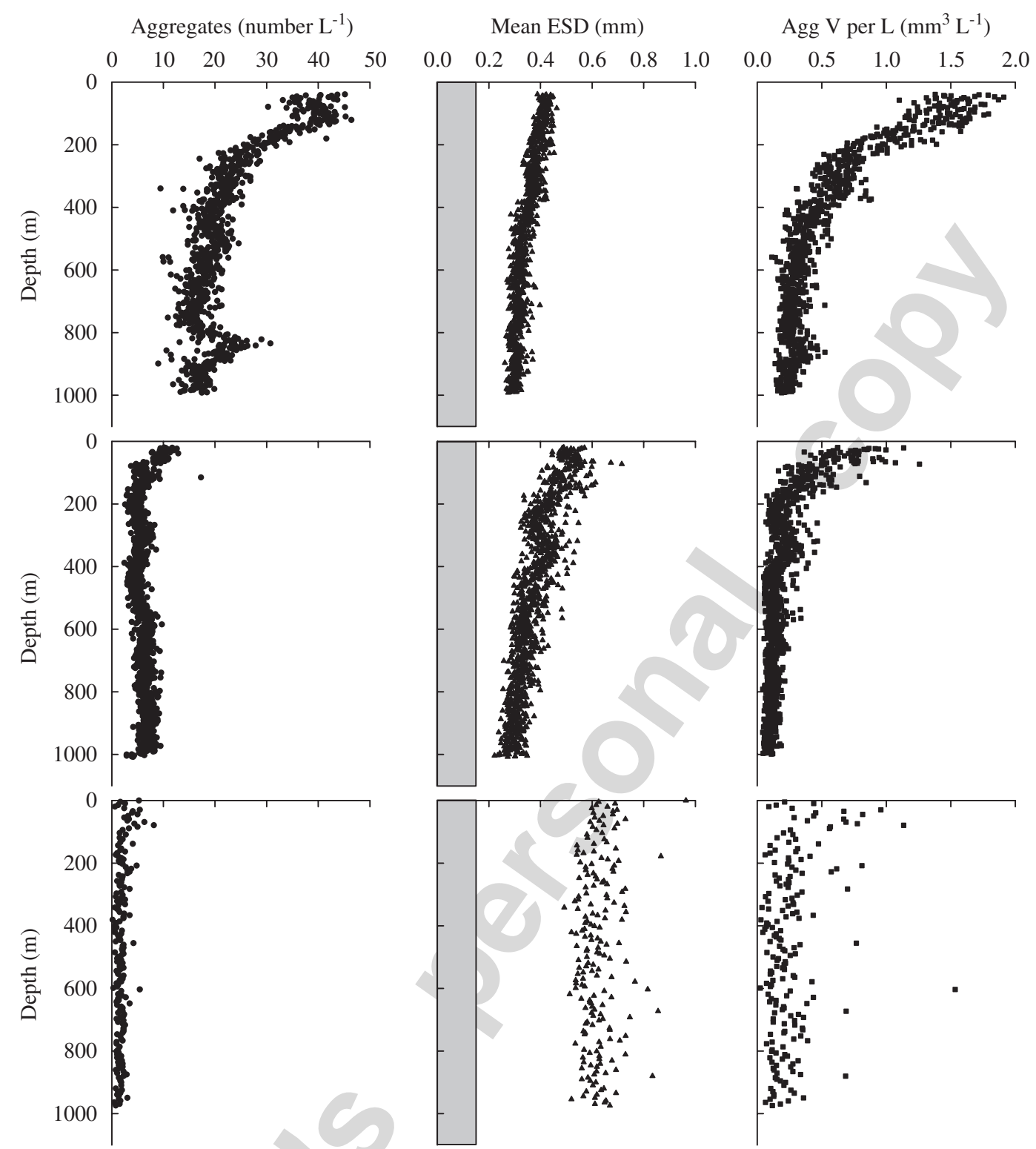

Fig. 1. Examples of aggregate number per liter, mean equivalent spherical diameter (ESD) for all particles $>0.15 \mathrm{~mm}$ at each depth, and volume of aggregates per liter (calculated from number and mean ESD) versus depth from video images. The upper panels depict one profile from the Southern Ocean at $48.9^{\circ} \mathrm{S}, 72.1^{\circ} \mathrm{E}$ (data from Gorsky and Picheral, 2004a). The middle panels show a profile from the eastern Atlantic at $20.5^{\circ} \mathrm{N}, 18.7^{\circ} \mathrm{W}$ (data from Gorsky, 2004) and the area in gray is below the detection limit of the camera. The bottom panels show a profile from the equatorial Pacific at $5.0^{\circ} \mathrm{N}, 179.8^{\circ} \mathrm{W}$ (data from Gorsky and Picheral, 2004b). A multitude of such data exist, for example, archived on Pangaea (http://www.pangaea.de/Info/).

and average size of aggregates drop off appreciably below the euphotic zone (Fig. 1), driving with them a drop in the total volume of aggregates per liter. This implies that degradation processes are strongly active in the upper few hundred meters and that processes in this zone bear considerable influence on the flux reaching deeper waters (Bishop et al., 1978, 1980).

Although cameras are a powerful means of investigating aggregates in the ocean, their instantaneous views of particle distributions may miss episodic pulses of material that contribute disproportionately to particle flux, such as events associated with phytoplankton blooms (Billett et al., 1983; Asper et al., 1992) or the breakdown of watercolumn stratification by convective mixing (Kemp et al., 2000). Such pulses of phytodetritus to the seafloor have been seen in all ocean basins in both coastal and open-ocean locations, and can, in the course of a few days to a few weeks, deliver the equivalent of the annual average carbon flux to the benthos (Beaulieu, 2002). This rapidly sedimented 
phytodetritus is typically dominated by diatoms (Beaulieu, 2002).

But even without necessarily capturing extreme events, camera profiles show a considerable spatial and temporal variability to the distribution of aggregates in the upper ocean. Aggregates have been seen accumulating at density discontinuities to form thin, high concentrated layers of POC (MacIntyre et al., 1995). In productive upwelling regimes, such as the Monterey Bay, California, aggregate number and total volume at a given sampling site have been seen to be 50-80 times higher during times of upwelling and high productivity than during winter months or El Niño years when upwelling and productivity are diminished (Pilskaln et al., 1998). Patchiness in aggregate distributions has been seen along a latitudinal transect in the equatorial Pacific (Gorsky et al., 2003). Diel variations in aggregate abundance and character have also been observed (Graham et al., 2000) and ascribed to the nightly vertical migrations of zooplankton who, by swimming, fragment marine snow they encounter into numerous smaller particles (Dilling and Alldredge, 2000; Goldthwait et al., 2004). Perhaps in the future, moored camera systems will provide us with a more complete data set on the spatial and temporal variability of flux.

\subsection{Organic components of particle flux}

The sinking flux of organic carbon (i.e., not including organic carbon excreted at depth by vertically migrating zooplankton [Steinberg et al., 2000], a process that is not addressed in this manuscript), occurs either as fecal pellets or as marine-snow-sized aggregates. Large aggregates in surface waters can be classified into four types (Alldredge and Silver, 1988), diatom, fecal, and miscellaneous aggregates, which are formed through coagulation, and mucus feeding webs, which are not. Aggregates consist of material, i.e., diatom cells, fecal pellets, or a mixture of phytoplankton, fecal, and detrital components, held together by TEP. Mucous feeding webs are gelatinous feeding structures, shed by organisms such as appendicularians and pteropods, that may scavenge smaller particles as they sink (Alldredge, 2005). All four types of marine snow are colonized by microbial and invertebrate organisms that live in and survive off of marine snow (Cho and Azam, 1988; Green and Dagg, 1997).
Although diatoms are not the only phytoplankton, they are the predominant producers of phytoplankton aggregates, because they are the only class of phytoplankton equivocally capable of voluminous production of the TEP that drives the aggregation process (Alldredge et al., 1993). Coccolithophorids (Engel et al., 2004) and Phaeocystis spp. (Passow and Wassmann, 1994; Hong et al., 1997) may also generate TEP, but fast-sinking TEPrich coccolithophorid aggregates (unequivocally formed by aggregation) have yet to be observed (see below). Other phytoplankton, like dinoflagellates or Phaeocystis spp., may be enclosed in aggregates (Riebesell et al., 1995; Alldredge et al., 1998), but have not been observed to form phytoplankton aggregates themselves, although the detrital matter of lysed and senescent phytoplankton will always form detrital aggregates and marine snow may be comprised of predominantly detrital components. At any rate, it is because of TEP and aggregation that POC during a thick bloom of relatively large diatoms stands a reasonable chance of being exported from the euphotic zone via rapidly sinking aggregates (Smetacek, 1985; Riebesell, 1991; Hill, 1992; Kiørboe et al., 1994; Passow et al., 1994; Logan et al., 1995), while, on the other extreme, POC produced by miniscule picoplankton will generally wind up in the microbial loop and be remineralized in surface waters (Legendre and Michaud, 1998; Wassmann, 1998), although picoplankton can sink when associated with fecal pellets, aggregates, and mucous feeding structures.

Fecal pellets may be the main vector for the sedimentation of the coccoliths of coccolithophorids. Individually, coccoliths have a sinking velocity of $0.1 \mathrm{~m} \mathrm{~d}^{-1}$ but, in situ, sink rapidly via their incorporation into larger particles. Coccoliths and whole coccolithophorids appear to most commonly sink within fecal pellets (Honjo, 1976, Honjo et al., 1982; Fischer et al., 1996), and disintegration of sinking fecal pellets may be responsible for the high concentrations of coccoliths observed in deep waters (Honjo, 1976).

Reports of intact coccolithophorids and coccoliths in gelatinous "aggregates" (Honjo, 1982; Cadee, 1985), which contain large amounts of fecal pellets and other phytoplankton and detritus (Rieman, 1989), provide another possibility for the sedimentation of coccolithophorid-derived material. Nothing appears to be known about how these mucous conglomerates formed, and, as noted above, the coagulation of coccolithophorids has 
never been observed. From the photographs and descriptions, these coccolith-rich conglomerates seem to be derivates of zooplankton feeding structures and fecal pellets. For example, appendicularians graze on coccolithophorids (Gorsky et al., 1999), and their discarded houses look very much like the mucous conglomerates described, as do the pseudo-feces salps generate when cleaning their feeding apparatuses.

Mucous feeding structures cast off by appendicularians (larvaceans) are by far the most important source of marine snow formed by zooplankton. These feeding structures may contribute around $30 \%$ of the POC flux in certain regions (Alldredge, 2005). Marine snow consisting of appendicularian houses differs notably from marine-snow-sized aggregates in that it does not fragment, potentially resulting in different transfer efficiencies during sinking. The potentially great contribution of appendicularian houses to POC flux means that the relatively scant attention that has been paid to them needs to be redressed so that a better understanding of their contribution on the global scale may be gained.

Miscellaneous marine snow is that, largely detrital in makeup, without a singular identifiable primary component. It may include the bodies, molts or tests of organisms such as copepods, radiolarians and planktonic foraminifera which at times contribute significantly to particle flux (Silver and Gowing, 1991; Rieman, 1989).

Despite the abundance of studies on the flux of POC to the deep sea, there is not currently consensus as to whether fecal pellets or aggregates are the main vectors for the sinking of POC into the deep sea. Many sediment-trap and large-volume filtration studies have traditionally led to the view that fecal pellets dominate POC flux (e.g., Bishop et al., 1977; Pilskaln and Honjo, 1987; Wassmann et al., 2000; Turner, 2002). Other sediment trap studies, deployment of cameras in the deep sea, studies of aggregation in the surface ocean, and observations of the accumulation of thick layers of diatom mats in sediments have led to an appreciation that brief and episodic pulses of aggregates can deliver to depth relatively large quantities POC in a fairly undegraded state (Billett et al., 1983; Fowler and Knauer, 1986; Kemp et al., 2000; Beaulieu, 2002; Turner, 2002). It is clear, however, that both aggregates and fecal pellets are important carriers of organic carbon to the deep sea and that their relative importance varies, for example, seasonally (e.g., Thibault et al., 1999), as the result of shifts in food web structure. The relative importance to flux of fecal pellets versus aggregates also likely varies with depth in the sea as bacteria decompose the TEP matrix of aggregates and deep-dwelling heterotrophs ingest, fragment, and otherwise repackage the sinking flux of POC.

Given the efforts that would be required to collect data at adequate temporal and spatial scales and resolution to make a global estimate of the relative importance the different components of POC flux at various depths, there is a temptation to turn to models to constrain the answer. Recent models combining particle dynamics, food webs, and sinking to predict POC fluxes (Kriest, 2002; Stemmann et al., 2004a, b) have been successful at reproducing regional particle fluxes and/or aggregate profiles measured by cameras. However, it is clear that there are many parameters regarding processes impacting aggregate number, volume, sinking speed, decomposition, etc., that are unknown or only poorly constrained, especially for the behavior of aggregates in deeper waters. Until these processes have been better identified and quantified, models will only be of limited use to estimate the relative importance of the different pathways by which POC leaves the euphotic zone, passes through the mesopelagic realm, and enters the deep sea and sediments.

\section{Relationships between mineral and organic carbon fluxes}

\subsection{The ballast hypothesis}

POC reaching the deep sea appears to do so in association with minerals. The fluxes of calcium carbonate and POC into sediment traps below $3000 \mathrm{~m}$ are correlated $\left(r^{2} \sim 0.7\right)$ (François et al., 2002; Klaas and Archer, 2002). There is also a weaker but still significant correlation between opal and POC fluxes into these traps (François et al., 2002; Klaas and Archer, 2002). These deep-trap data also suggest that by the time they reach the deep sea, sinking particles contain a fairly constant $5 \mathrm{wt} \%$ of organic carbon (Armstrong et al., 2002).

Although the impact of mineral "ballast" on fecal pellet or aggregate density has long been recognized (Small et al., 1979; Honjo, 1982; Fowler and Knauer, 1986), it has been only recently proposed that such mineral "ballast" is critical to POC flux (Armstrong et al., 2002; François et al., 2002; Klaas 
and Archer, 2002). Starkly in contrast with the idea that aggregation in surface waters drives the sinking and sedimentation of $\mathrm{POC}$, is the hypothesis that minerals control the fraction of surface primary production that reaches the seabed by protecting the organic matter from oxidation or by increasing the density, and thus the sinking velocity, of aggregates (Armstrong et al., 2002; François et al., 2002; Klaas and Archer, 2002). Owing to the greater correlation between calcium carbonate and POC, calcium carbon is further taken to be the mineral primarily responsible for the sedimentation of POC (François et al., 2002; Klaas and Archer, 2002). This hypothesis, which has been termed the ballast hypothesis, has had a large impact on the scientific community, triggering a lively discussion (with the three papers already collectively fetching 133 citations).

The alternative interpretation of the correlations is that it is the flux of POC that controls the mineral flux by sinking aggregates scavenging suspended minerals too small to sink on their own (Honjo, 1982; Passow, 2004). In this view, the $5 \mathrm{wt} \%$ of organic carbon of deep sea particles represents the carrying capacity of organic aggregates for minerals (Passow, 2004), a hypothesis which is supported by laboratory experiments (Passow and De La Rocha, 2006).

A third possibility is that, despite the correlation, there is no direct connection between mineral and POC fluxes in the deep sea. A correlation between a decline in the human birth rate and the size of the stork population in Germany (Sies, 1988), for example, did not convince anyone of a correspondence between storks and the delivery of babies.

\subsection{The higher variability of opal to POC ratios compared to calcium carbonate to POC ratios}

Although the weaker correlation between sinking POC and opal than between sinking POC and calcium carbonate has been interpreted as a greater importance of calcium carbonate to sinking fluxes (Klaas and Archer, 2002), there are alternative explanations for this observation. The first and foremost is that the opal to POC ratio of particles near the surface is quite variable between ocean basins, possibly due to basin-scale differences in the supply ratio of silicic acid and nitrate (Ragueneau et al., 2000). Basin-scale differences in the proportion of primary production that is carried out by diatoms are clearly reflected in global silica to POC data from various depths predominantly above
$3000 \mathrm{~m}$ (Fig. 2), which show not one but many different opal to POC relationships with slopes unique to geographic areas (Ragueneau et al., 2000). In areas of high silica production, the silica to POC relationship has a steep slope, e.g., $2.2 \mathrm{~mol} \mathrm{Si} \mathrm{per}$ mole $\mathrm{C}$ for the North Pacific and $1.5 \mathrm{~mol} \mathrm{Si} \mathrm{per} \mathrm{mole}$ $\mathrm{C}$ for the California Current (Fig. 2). Areas not dominated by diatoms show shallower slopes, e.g., $0.13 \mathrm{~mol} \mathrm{Si}$ per mole $\mathrm{C}$ in the Arabian Sea and $0.09 \mathrm{~mol} \mathrm{Si}$ per mole $\mathrm{C}$ in the Norwegian and Greenland Seas. Global averaging of these different relationships leads to a poor, although significant, correlation $\left(r^{2}=0.20, p=0.01\right.$; see Fig. 2). In contrast, the slopes and intercept of the POC to $\mathrm{CaCO}_{3}$ relationships are similar, the North Pacific data aside, leading to a good correlation between POC and $\mathrm{CaCO}_{3}$ over various geographic regions (e.g., $r^{2}=0.6, p=0.01$ for all data on Fig. 2 of this paper, and $r^{2}=0.7$ for Fig. 4 in Milliman, 1993) although planktonic carbonate production appears slightly higher in high production areas of the Atlantic than in those of the Pacific, suggesting that the lower fraction of diatom production is partially compensated by coccolithophorid production.

Morphological and ecological differences between diatoms and coccolithophorids also may contribute to the more homogenous calcium carbonate to POC signal at depth compared to the opal to POC signal. Whereas the organic part of a diatom cell is trapped within its opal frustule, the coccoliths of each coccolithophorid cell are only attached relatively loosely, in the outer layer of the coccosphere. Aggregation, which commonly terminates diatom blooms, additionally keeps both fractions of the diatom cell - the POC and the opal - together. It is not unusual for diatom aggregates to arrive at the seabed relatively intact (Beaulieu, 2002), without significant chance for homogenization during fragmentation and reaggregation otherwise occurring during downward transport. Coccolithophorids, in contrast, easily shed the biominerals they produce, with the living cells of some species (e.g., the cosmopolitan Emiliania huxleyi) releasing them directly. E. huxleyi blooms are also commonly terminated by viral attacks that lyse the cells (Castberg et al., 2001), dispersing coccoliths. Grazing is another important loss process (Nejstgaard et al., 1997; Schnetzer and Steinberg, 2002), which would separate coccoliths from coccolithophore cells or package coccoliths into fecal pellets that are easily disrupted and repackaged again and again at depth (Honjo, 1982). 
Thus, whereas a large part of the POC formed by diatoms will remain associated with the opal frustule during sinking, the liths shed from coccolithophorids will not be as strongly associated with the organic matter of the organism that produced them, leaving the calcium carbonate more open to attaining homogenous mineral to $\mathrm{POC}$ ratios during processes of aggregation, sinking, fragmentation, and reaggregation. As a consequence of these differences in how the respective biominerals find their way into aggregates, it may be expected that regional variability in the opal to POC ratio observed during production is transferred to depth, whereas any spatial or temporal variability in the carbonate to POC ratio will be more readily obscured.

Regional differences in the opal to POC ratio carry through to deeper waters (e.g., Fig. 6 in Klaas and Archer, 2002). The data that yielded the relatively weak correlation between opal and POC fluxes should not have had a single regression line fit through them, as the data cluster into two different sets, one with an opal to POC ratio of roughly $4 \mathrm{mg} \mathrm{mg}^{-1}\left(0.8 \mathrm{~mol} \mathrm{~mol}^{-1}\right)$, and another with a ratio of approximately $32 \mathrm{mg} \mathrm{mg}^{-1}\left(6.4 \mathrm{~mol} \mathrm{~mol}^{-1}\right)$. The
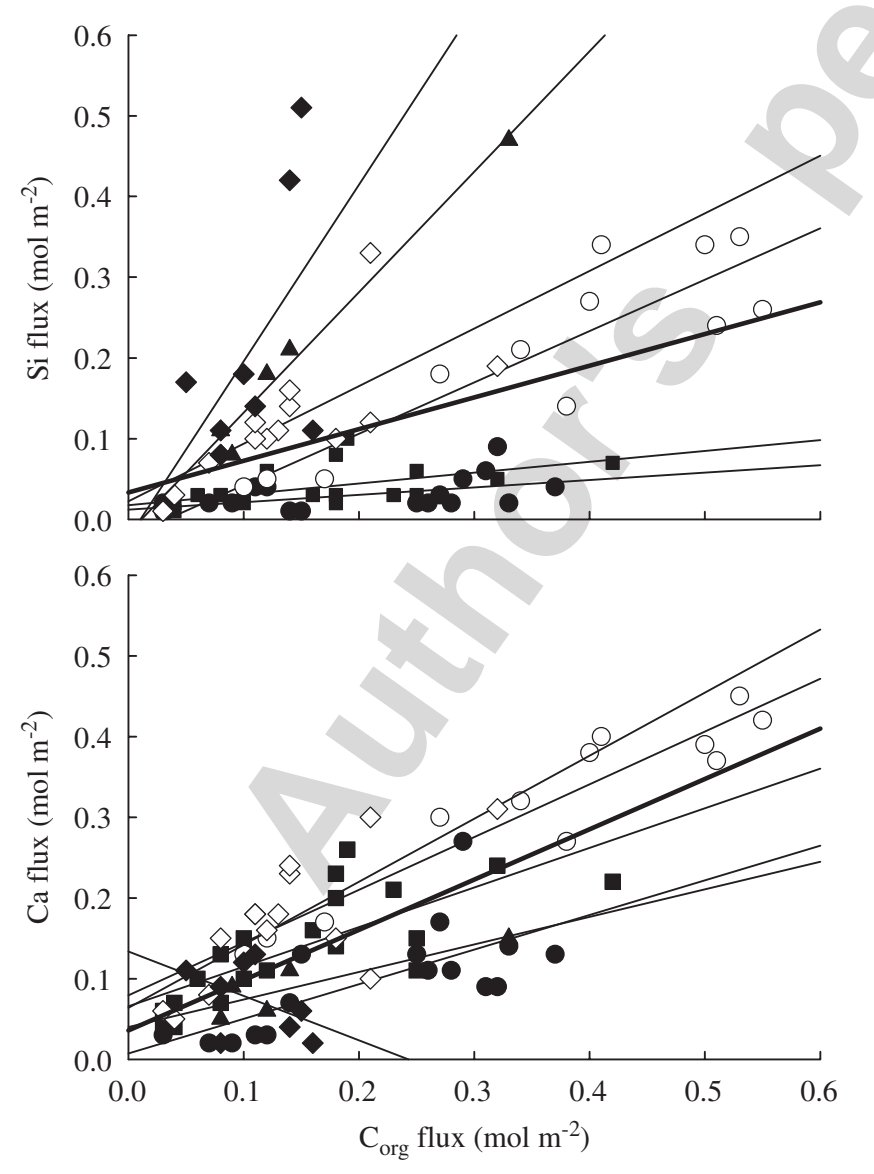

low correlation between opal and POC flux at depth observed by Klaas and Archer (2002) may not reflect that opal is an ineffective carrier of POC to depth, but that the variable opal to POC ratio of organic aggregates produced in surface waters leads to systematic variability in the opal to POC ratios of sinking particles below $3000 \mathrm{~m}$. And since diatoms far more than any other phytoplankton are responsible for the production of phytoplankton aggregates, and because they carry out half of the primary production in the world ocean (Nelson et al., 1995), it would follow that particles reaching depth would tend to have higher, not lower, opal to POC ratios than non-sinking particles, contributing further to the image of opal as an "inefficient carrier" of POC to the deep.

The homogenization of the calcite to POC ratio with depths suggests that there may be a considerable pool of non-sinking calcite, such as coccoliths

Fig. 2. Molar fluxes of biogenic silica and POC (upper panel) and calcium carbonate and POC (lower panel) into a suite of sediment traps of various depths (shallow and deep) in different ocean regions. The mean of the average sediment trap depths at each site is $2200 \pm 450 \mathrm{~m}$. The bold trend lines are for all data on each plot and have a value of $y=0.39 x+0.03\left(r^{2}=0.20 ; p=0.01\right.$; $n=77)$ for silica and POC, and $y=0.62+0.04\left(r^{2}=0.60\right.$; $p=0.01 ; n=76$ ) for calcium carbonate and POC. The lighter trend lines shown in the upper panel are, clockwise from vertical, $y=2.19 x-0.23\left(r^{2}=0.28 ; p>0.05 ; n=8\right)$ for the North Pacific (filled diamonds), $y=1.49 x-0.02\left(r^{2}=0.98 ; p=0.01 ; n=5\right)$ for the California Current (Pacific) (filled triangles), $y=0.71 x+0.02$ $\left(r^{2}=0.51 ; p=0.01 ; n=14\right)$ for the Equatorial Pacific (open diamonds), $y=0.64 x-0.02\left(r^{2}=0.78 ; p=0.01 ; n=12\right)$ for the Arabian Sea (open circles), $y=0.13 x+0.02\left(r^{2}=0.33 ; p=0.01\right.$; $n=21$ ) for the Atlantic Ocean (filled squares), and $y=0.09 x+0.01\left(r^{2}=0.24 ; p=0.05 ; n=17\right)$ for the Norwegian and Greenland Seas (filled circles). The lighter trend lines in the lower panel are $y=-55 x+0.13\left(r^{2}=0.23 ; p>0.05 ; n=8\right)$ for the North Pacific (filled diamonds), $y=0.34 x+0.04\left(r^{2}=0.75\right.$; $p>0.05 ; n=5$ ) for the California Current (Pacific) (filled triangles), $y=0.78 x+0.06\left(r^{2}=0.54 ; p=0.02 ; n=14\right)$ for the Equatorial Pacific (open diamonds), $y=0.65 x-0.08\left(r^{2}=0.90\right.$; $p=0.01 ; n=12)$ for the Arabian Sea (open circles), $y=0.49 x+0.07\left(r^{2}=0.57 ; p=0.01 ; n=21\right)$ for the Atlantic Ocean (filled squares), and $y=0.43 x+0.01\left(r^{2}=0.48 ; p=0.01\right.$; $n=16$ ) for the Norwegian and Greenland Seas (filled circles). Data have been replotted from Ragueneau et al., 2000 (and originally came from Dymond and Lyle, 1982; Dymond and Collier, 1988; Fischer et al., 1988; Wefer et al., 1988; Roth and Dymond, 1989; Wefer and Fischer, 1991; Honjo and Manganini, 1993; Wefer and Fischer, 1993; Dymond and Lyle, 1994; Von Bodungen et al., 1995; Fischer and Wefer, 1996; Honjo et al., 1995; Wong et al., 1999; Lampitt et al., 2001, and Ragueneau et al., 2001) , although the data from the Southern Ocean bearing no significant relationship between POC and silica $\left(r^{2}=0.37\right.$; $p>0.05 ; n=8)$ or between POC and calcium carbonate $\left(r^{2}=0.02 ; p>0.05 ; n=8\right)$ have been omitted. 
or fragments thereof, which are picked up by all types of sinking aggregates up to the carrying capacity of these aggregates (Passow and De La Rocha, 2006). Well-preserved coccoliths are indeed found suspended in all oceans, even in waters deeper than the lysocline (Honjo, 1976). And small, nonsinking foraminiferan tests, awaiting scavenging by aggregates after high primary production events at the surface, are also found in deeper waters (Schiebel, 2002). The lack of a comparable homogenization of the opal to POC ratios at depth suggests that there is no comparable pool of suspended opal. Alternatively, the lack of homogenization of the opal to POC ratio also could be tied to the low binding efficiency for opal to polysaccharide matrixes (Moulin and Moulin, 2001; Moulin et al., 2004) such as hold aggregates together (Alldredge et al., 1993), which may prevent organic aggregates from effectively scavenging suspended silica fragments.

A possible argument against a deep pool of unsinking calcium carbonate being the reason for the homogeneity of the calcium carbonate to POC ratios is that large, rapidly sinking tests from foraminifera and pteropods make significant contributions to the calcium carbonate flux. Coccolithophorids are thought to be responsible for the production of about $50-70 \%$ of the planktonic carbonate production, pteropods contribute about 10\% (Berner and Honjo, 1981; Schiebel, 2002), and planktonic foraminifera contribute the remaining $20-40 \%$.

Foraminiferal tests are predominantly cast from the foraminifera en masse after completion of the life cycle of these animals. These tests are generally fairly large and do not need to be scavenged by aggregates to sink rapidly, although they may collect aggregates on their way down. Thus a signal very different from that of coccoliths and independent of POC sinking would be expected from these foraminiferan tests, although this is not discernible in the trap data. Possibly these events are so rare and the temporal-spatial resolution of traps so low that the signals from large foraminifera and pteropods are nothing but noise in the global correlations.

Unfortunately for the evaluation of this idea, few trap data exist where the calcium carbonate flux has been separated into coccolith versus foraminiferal flux. However, two sediment traps positioned in the eastern equatorial Atlantic at $1000 \mathrm{~m}$ depth and off Namibia at $2500 \mathrm{~m}$ depths (Baumann et al., 2003) provide enough data for a preliminary analysis. These traps suggest that the correlation between POC and coccolith calcium carbonate flux is appreciably tighter than between POC and foraminiferan calcium carbonate flux (Fig. 3). In the traps offshore of Namibia, the correlations between POC and different fractions of calcium carbonate flux are significant for both coccolith carbonate $\left(r^{2}=0.73\right.$, $n=20, p=0.01)$ and foraminiferan carbonate $\left(r^{2}=0.59, \quad n=20, \quad p=0.01\right)$, where coccoliths dominate the calcium carbonate flux (median of $46 \%$ versus $9 \%$ for foraminifera, the rest being pteropods). While there is a significant correlation between POC flux and coccolith carbonate $\left(r^{2}=0.63, n=15, \quad p=0.01\right)$ at the equatorial Atlantic site where foraminifera dominate the carbonate flux (median of $20 \%$ for the coccolith fraction and $41 \%$ for the foraminifera fraction),

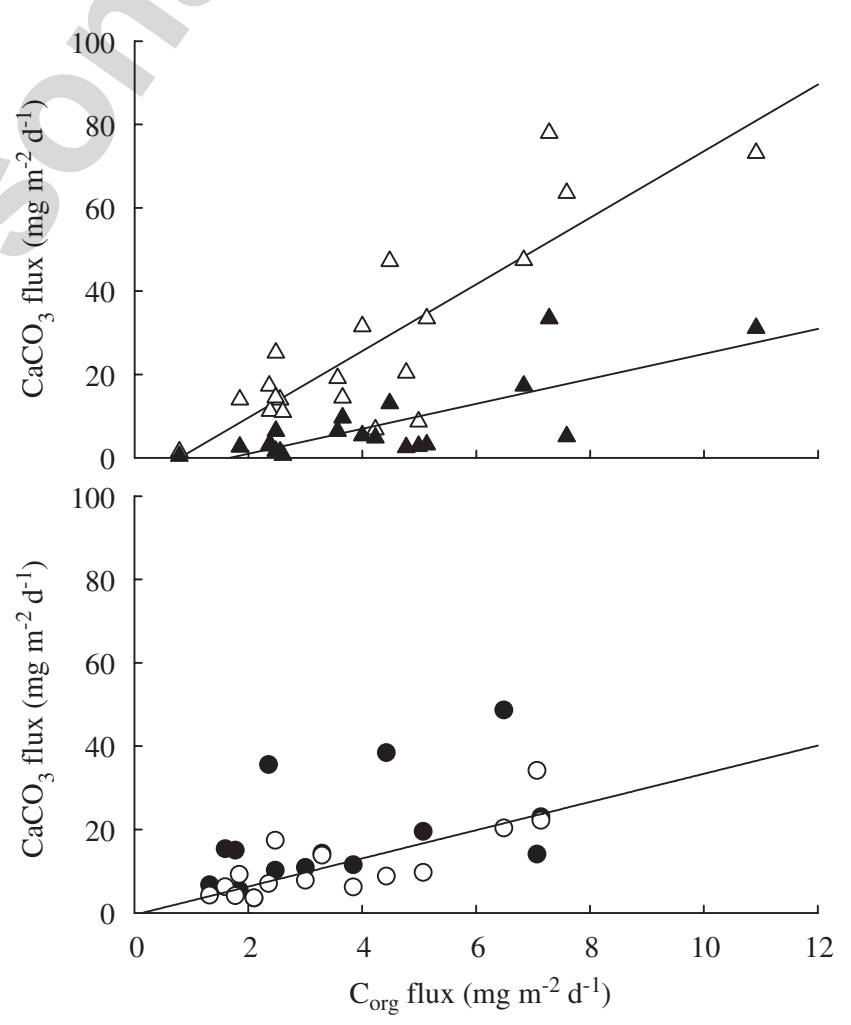

Fig. 3. Mass fluxes of coccolith carbonate (open symbols) and foraminiferan carbonate (filled symbols) versus POC flux from sediment traps in (upper panel) Namibia $\left(29^{\circ} 12.0^{\prime} \mathrm{S}, 13^{\circ} 07.0^{\prime} \mathrm{E}\right.$; water depth $3055 \mathrm{~m}$ ) and (lower panel) the equatorial Atlantic $\left(00^{\circ} 04.5^{\prime} \mathrm{N}, 10^{\circ} 46.1^{\prime} \mathrm{W}\right.$; water depth $\left.4141 \mathrm{~m}\right)$. Data are from Baumann et al., 2003. The significant regression lines shown in the upper panel are $y=8.0 x-6.3 ; r^{2}=0.73$ (open symbols) and $y=3.0 x-5.0 ; r^{2}=0.73$ (filled symbols), and in the lower panel it is $y=3.4 x-0.48 ; r^{2}=0.64$ (open symbols). There is not a significant correlation between foraminferan carbonate and POC flux in the bottom panel. 
there is no correlation between POC flux and foraminiferal carbonate $\left(r^{2}=0.25, n=14 ; p>0.05\right)$.

All things considered, an understanding of the interactions between sinking POC and minerals in the deep sea would be improved by data on the types and concentrations of non-sinking mineral particles in the deep sea. There are, of course, considerable data on the number of particles present in the deep sea, on the abundance of minerals sinking into sediment traps, or on material collected through large-volume, in situ pumps, that could be either sinking or suspended. But there is no way to use these data to constrain the background concentration of small, non-sinking particles of clay, opal, and calcium carbonate in the meso- and bathypelagic zones where they seem to play an important role in the sinking of POC.

\subsection{Impact of minerals on the decomposition and sinking velocities of aggregates}

If the hypothesis that minerals control the flux of POC to depth is correct, minerals must either increase the sinking velocities of organic aggregates or protect them from microbial degradation (Armstrong et al., 2002; François et al., 2002; Klaas and Archer, 2002). So far there has not been conclusive evidence in support of either idea.

In sediments, labile organic matter may be preserved via complexation to mineral surfaces (Keil et al., 1994), the composition of total hydrolyzable amino acids changes markedly over time due to the selective degradation of compounds (Ingalls et al., 2003), and the organic matter that is preserved over long time scales is that which has become associated with minerals (Hedges and Keil, 1995). In the water column, however, although adsorption onto minerals has been seen to reduce the activities of extracellular enzymes (Tietjen and Wetzel, 2003), organic matter-mineral associations have not been observed to have an impact on POC. The composition of total hydrolyzable amino acids of sinking organic matter does not change much with depth between the euphotic zone and seafloor (Ingalls et al., 2003). Because compounds differ in the strength of their association with mineral surfaces, the lack of selective decay of amino acids in the water column suggests that minerals do not affect the decay of sinking POM. The only currently probable exception to this would be the organic templates for silicification and calcification that are entombed within biomineral matrixes and assumed to be unavailable to microbial and enzyme attack.

Incorporation of minerals into diatom aggregates has not been observed to necessarily increase their sinking velocities (Hamm, 2002), and the sinking velocities of particles in the deep sea appear to be tied more closely to their POC content than to their mineral content (Berelson, 2002). One possibility for the lack of a straightforward relationship between the mineral content of an organic aggregate and its sinking velocity is that the incorporation of minerals into aggregates reduces their size. A recent study subjected mixed copepod fecal pellet and diatom aggregates to various amounts of suspended minerals in rolling tanks in a laboratory (Passow and De La Rocha, 2006). At concentrations of minerals (e.g., $1500-37,000 \mu \mathrm{g} \mathrm{L}^{-1}$ ), equivalent to the amount an aggregate might encounter while sinking $3000 \mathrm{~m}$, a considerable increase in aggregate number and a considerable decrease in aggregate volume was observed (Table 1). Such fragmentation did not occur at low concentrations of minerals $\left(7-400 \mu \mathrm{g} \mathrm{L}^{-1}\right)$, but the size of aggregates still decreased as mineral content increased. Thus (effects of changes in porosity aside), while the addition of density should increase the sinking velocities of particles (Eq. (2)), the simultaneous reduction in the radii of the aggregates should have the opposite effect on sinking velocities, diminishing or overwhelming the effect of the density addition.

Although changes in the porosity and sinking velocity of the aggregates with mineral addition were not measured by Passow and De La Rocha (2006), enough data were presented (Table 1) for rough estimates of some of these parameters to be made (Table 2) for aggregates containing negligible additions of $\mathrm{CaCO}_{3}$ (i.e., a POC to dry weight ratio of 0.14 ) versus those exhibiting the $5 \mathrm{wt} \%$ organic $\mathrm{C}$ of material sinking through the deep sea (i.e., a gain

Table 1

Character of organic aggregates exposed to different concentrations of suspended calcium carbonate in rolling tanks

\begin{tabular}{rrll}
\hline $\begin{array}{r}\left.\mathrm{CaCO}_{3}\right] \\
\left(\mu \mathrm{g} \mathrm{L}^{-1}\right)\end{array}$ & $V\left(\mathrm{~mm}^{3}\right)$ & $\begin{array}{l}W_{\mathrm{dry}} / V \\
\left(\mu \mathrm{gmm}^{-3}\right)\end{array}$ & $\begin{array}{l}\mathrm{POC} / W_{\mathrm{dry}} \\
\left(\mathrm{mg} \mathrm{C} \mathrm{mg}^{-1}\right)\end{array}$ \\
\hline 7 & 149 & 2.8 & 0.14 \\
40 & 71 & 3.6 & 0.14 \\
400 & 400 & 1.0 & 0.14 \\
1500 & 43 & 16.4 & 0.06 \\
7000 & 4 & 98.1 & 0.04 \\
\hline
\end{tabular}

Data are from Passow and De La Rocha (2006). 
Table 2

Estimates of wet density, porosity, density relative to seawater, and $r^{2}(\Delta \rho)$ of the aggregates listed in Table 1

\begin{tabular}{rlllll}
\hline$\left[\mathrm{CaCO}_{3}\right]\left(\mu \mathrm{g} \mathrm{L}^{-1}\right)$ & $\rho_{\mathrm{m}}\left(\mathrm{g} \mathrm{cm}^{-3}\right)$ & $P$ & $\Delta \rho\left(\mathrm{mg} \mathrm{cm}^{-3}\right)$ & $r^{2}(\Delta \rho)\left(\mathrm{mg} \mathrm{cm}^{-1}\right)$ & $\begin{array}{l}(1-P) r^{2}(\Delta \rho) \\
\left(\mathrm{mg} \mathrm{cm}^{-1}\right)\end{array}$ \\
\hline 7 & 1.25 & 0.998 & 0.5 & 0.02 & 0.00005 \\
40 & 1.25 & 0.997 & 0.6 & 0.03 & 0.00008 \\
400 & 1.25 & 0.999 & 0.2 & 0.01 & 0.00001 \\
1500 & 2.13 & 0.992 & 9 & 0.25 & 0.003 \\
7000 & 2.39 & 0.959 & 56 & 0.31 & 0.02 \\
\hline
\end{tabular}

of $10-20 \mathrm{~g}$ of $\mathrm{CaCO}_{3}$ for every $\mathrm{g}$ of POC). Estimates of the density differences between the low-mineral versus mineral-laden aggregates may be made, and from them, calculations of porosity and excess density. From these estimates, rough, relative predictions can be made for the impact of mineral addition on sinking rates.

The wet density of the material making up the aggregates $\left(\rho_{\mathrm{sm}}\right)$ in each treatment can be estimated from the fraction of the weight contributed by the organic aggregate $\left(X_{\text {agg }}\right)$ and the fraction contributed by the $\mathrm{CaCO}_{3}\left(X_{\mathrm{CaCO}_{3}}\right)$, assuming a $\mathrm{CaCO}_{3}$ free aggregate density of $1.25 \mathrm{~g} \mathrm{~cm}^{-3}$ (the wet density of a copepod fecal pellet; Komar et al., 1981) and a calcium carbonate density of $2.8 \mathrm{~g} \mathrm{~cm}^{-3}$ (Smayda, 1970):

$\rho_{\mathrm{sm}}=\chi_{\mathrm{agg}} 1.25+\chi_{\mathrm{CaCO}_{3}} 2.8$.

The significant addition of $\mathrm{CaCO}_{3}$ to aggregates in this experiment nearly doubled the wet density of the material making up the aggregates (the 1500 and $7000 \mu \mathrm{g} \mathrm{L}^{-1}$ treatments on Table 2).

The porosity $(P)$ of the calcium carbonatecontaining aggregates can then be estimated from their dry weight $\left(w_{\text {dry }}\right)$, volume $(V)$, and the calculated wet density of their material components (Alldredge and Gotschalk, 1988):

$P=\frac{w_{\mathrm{dry}} / \rho_{\mathrm{sm}}}{V}$.

This yields porosities of $99.7-99.9 \%$ at lower particle concentrations for the aggregates containing negligible amounts of $\mathrm{CaCO}_{3}$ (Table 2), in line with porosities observed for aggregates in marine surface waters (Alldredge and Gotschalk, 1988). With the addition of $\mathrm{CaCO}_{3}$, however, aggregates became more compact, showing porosities of $99.2 \%$ and $95.9 \%$ (Table 2). An additional treatment, with initial suspended calcium carbonate concentrations of $37,000 \mu \mathrm{g} \mathrm{L}^{-1}$, which has not been shown in
Tables 1 and 2 because the fragmented aggregates numbered in the thousands and were too small to enumerate (Passow and De La Rocha, 2006), would have had porosities considerably lower than $95.9 \%$.

The excess density $(\Delta \rho)$ of the aggregates in the experiment over that of seawater may be then calculated (Alldredge and Gotschalk, 1988) as

$\Delta \rho=\frac{w_{\text {dry }}}{V}\left(1-\frac{\rho_{\text {sw }}}{\rho_{\text {sm }}}\right)$,

where $\rho_{\text {sw }}$ is the density of seawater. The aggregates that picked up significant quantities of $\mathrm{CaCO}_{3}$ increased their excess density by $20-130$ times over the average of $0.4 \mathrm{~g} \mathrm{~cm}^{-3}$ of the mixed-composition aggregates lacking significant additions of $\mathrm{CaCO}_{3}$ (Table 2). Again, increases in the $37,000 \mu \mathrm{g} \mathrm{L}^{-1}$ treatment, had the multitude of particles produced been quantifiable, would have been greater than this.

The rough impact of the change in excess density on sinking velocities $(W)$ can be calculated, taking the change in the radii and porosity of the particles into account, according to Stokes' settling (Eq. (2)). Changes in the porosity, material wet density, and size of the aggregates due to mineral incorporation will impact $(1-P) r^{2}(\Delta \rho)$ only, with this term then giving the factor increase in sinking velocity in each condition. Values of $(1-P) r^{2}(\Delta \rho)$ for the $\mathrm{CaCO}_{3}-$ containing aggregates, at $0.003-0.02 \mathrm{mg} \mathrm{cm}^{-1}$, are $70-560$ times greater than the $4 \times 10^{-5} \mathrm{mg} \mathrm{cm}^{-1}$ of the relatively $\mathrm{CaCO}_{3}$-free aggregates, suggesting that the addition of minerals does indeed significantly increase aggregate sinking velocities. To break this down into the various parameters: $r^{2}$ shifted by a factor of $0.1, \Delta \rho$ by a factor of 130 , and $(1-P)$ by a factor of 40 . Thus while the decrease in porosity makes a significant contribution to the predicted increase in sinking velocity of these aggregates, the greater cause is the addition of density. 
These are certainly nothing more than ballpark estimates with large errors on them, but they suggest that incorporated minerals decrease the porosity and increase the density and sinking velocities of aggregates, despite fragmenting them into smaller particles. Given the mineral concentrations and time spans used by Passow and De La Rocha (2006) in their experiment, by the time aggregates reach the deep sea, even from open-ocean locations, they could have scavenged enough minerals to be sinking 1-2 orders of magnitude more quickly than they would have been in surface waters. The critical question for the "ballast hypothesis" is whether or not aggregates ever pick up a sufficient quantity of minerals early enough to speed them through the upper $1000 \mathrm{~m}$ of the water column where most of the degradation of POC occurs. Further work is also needed to quantify more directly and accurately the impact of mineral scavenging onto aggregate density, porosity, and sinking velocities.

\section{Concluding remarks}

Useful predictions on responses of the biological pump to global climate change are a great challenge, which can only be met by combining a mechanistic understanding of the functioning of organisms and ecosystems with globally quantitative estimates of the cycling of elements. Data currently exist for at least rough calculations of the fragmentation of organic aggregates by swimming zooplankton to be made, for example, and for ballpark estimates of the change in aggregate size, porosity, and sinking rate due to mineral scavenging to be included in models. Further experimental and observational work is necessary to improve our quantitative understanding of these two processes.

This paper has attempted to highlight areas where further research would result in the greatest gains in our ability to include more complexity into models of the biological carbon pump. These areas are:

- the fraction of sinking POC flux attributable to appendicularians, since current estimates of the contribution of this mostly overlooked vector are as high as $30 \%$ (Alldredge, 2005);

- the mechanism of transport of coccoliths and coccolithophorid POC to depth (i.e., in fecal pellets or via another pathway) and their overall flux;

- the impact of TEP on fluid flow through the pore space of aggregates;
- the abundance and distribution of zooplankton in the ocean and the volume of water disturbed by different species as they swim;

- loss of aggregates and POC due to the activity of microbes and zooplankton;

- the accumulation of minerals on organic aggregates and the effect of minerals on aggregate character and sinking velocity, and following from that;

- the distribution, abundance, and characteristics of non-sinking mineral particles in the meso- and bathypelagic zones; and

- the distribution, abundance, size, and physical attributes of organic aggregates throughout the world ocean (including depths below $1000 \mathrm{~m}$ ).

\section{Acknowledgements}

We thank the organizers of the Chapman conference on rain ratios for bringing together a diverse group of oceanographers, fostering the interaction of people who usually do not. We also thank Gerhard Fischer, who shared his raw data so that we could investigate the relationship between coccolithophorid and foraminiferan flux, and D. Wolf-Gladrow and two anonymous reviewers for comments that greatly improved the manuscript.

\section{References}

Alldredge, A.L., 2000. Interstitial dissolved organic carbon (DOC) concentrations within sinking marine aggregates and their potential contribution to carbon flux. Limnology and Oceanography 45, 1245-1253.

Alldredge, A.L., 2005. The contribution of discarded appendicularian houses to the flux of particulate organic carbon from oceanic surface waters. In: Gorsky, G. (Ed.), Response of Marine Ecosystems to Global Change: Ecological Impact of Appendicularians. GB Science Publishers-Editions Scientifiques, Paris, pp. 309-326.

Alldredge, A.L., Gotschalk, C., 1988. In situ settling behavior of marine snow. Limnology and Oceanography 33, 339-351.

Alldredge, A.L., Silver, M.W., 1988. Characteristics, dynamics, and significance of marine snow. Progress in Oceanography 20, 41-82.

Alldredge, A.L., Passow, U., Logan, B.E., 1993. The abundance and significance of a class of large, transparent organic particles in the ocean. Deep-Sea Research I 40, 1131-1140.

Alldredge, A.L., Passow, U., Haddock, S.H.D., 1998. The characteristics and transparent exopolymer (TEP) content of marine snow formed from thecate dinoflagellates. Journal of Plankton Research 20, 393-406.

Andersson, J.H., Wijsman, J.W.M., Herman, P.J., Middelburg, J.J., Soetaert, K., Heip, K., 2004. Respiration patterns in the deep sea. Geophysical Research Letters 31. 
Antia, A.N., 2005. Particle associated dissolved elemental fluxes: revising the stoichiometry of mixed layer export. Biogeosciences Discussions 2, 275-302.

Antia, A.N., et al., 2001. Basin-wide particulate carbon flux in the Atlantic Ocean: regional export patterns and potential for atmospheric $\mathrm{CO}_{2}$ sequestration. Global Biogeochemical Cycles 15, 845-862.

Armstrong, R.A., Lee, C., Hedges, J.I., Honjo, S., Wakeham, S.G., 2002. A new, mechanistic model for organic carbon fluxes in the ocean based on the quantitative association of POC with ballast minerals. Deep-Sea Research II 49, 219-236.

Arnosti, C., 1996. A new method for measuring polysaccharide hydrolysis rates in marine environments. Organic Geochemistry $25,105-115$.

Arnosti, C., Durkin, S., Jeffrey, W.H., 2005. Patterns of extracellular enzyme activities among pelagic marine microbial communitieis: implications for cycling of dissolved organic carbon. Aquatic Microbial Ecology 38, 135-145.

Asper, V.L., Smith Jr., W.O., 2003. Abundance, distribution and sinking rates of aggregates in the Ross Sea, Antarctica. DeepSea Research I 50, 131-150.

Asper, V.L., Deuser, W.G., Knauer, G.A., Lohrenz, S.E., 1992. Rapid coupling of sinking particle fluxes between surface and deep ocean waters. Nature 357, 670-672.

Azetsu-Scott, K., Passow, U., 2004. Ascending marine particles: significance of transparent exopolymer particles (TEP) in the upper ocean. Limnology and Oceanography 49, 741-748.

Banse, K., 1990. New views on the degradation and disposition of organic particles as collected by sediment traps in the open ocean. Deep-Sea Research A37, 1177-1195.

Baumann, K.-H., Böckel, B., Donner, B., Gerhardt, S., Henrich, R., Vink, A., Volbers, A., Willens, H., Zonneveld, K.A.F., 2003. Contribution of calcareous plankton groups to the carbonate budget of South Atlantic surface sediments. In: Wefer, G., Mulitza, S., Ratmeyer, V. (Eds.), The South Atlantic in the Late Quaternary: Reconstruction of Material Budgets and Current Systems. Springer, Berlin, pp. 81-99.

Beaulieu, S.E., 2002. Accumulation and fate of phytodetritus on the sea floor. Oceanography and Marine Biology.

Berelson, W.M., 2002. Particle settling rates increase with depth in the ocean. Deep-Sea Research II 49, 237-251.

Berner, R.A., Honjo, S., 1981. Pelagic sedimentation of aragonite: its geochemical significance. Science 211, 940-942.

Billett, D.S.M., Lampitt, R.S., Rice, A.L., Mantoura, R.F.C., 1983. Seasonal sedimentation of phytoplankton to the deep sea benthos. Nature 302, 520-522.

Bishop, J.K.B., Ketten, D.K., Edmond, J.M., 1978. The chemistry, biology and vertical flux of particulate matter from the upper $400 \mathrm{~m}$ of the Cape Basin in the southeast Atlantic Ocean. Deep-Sea Research 25, 1121-1161.

Bishop, J.K.B., Edmond, J.M., Ketten, D.R., Bacon, M.P., Silker, W.B., 1977. The chemistry, biology, and vertical flux of particulate matter from the upper $400 \mathrm{~m}$ of the equatorial Atlantic Ocean. Deep-Sea Research 24, 511-548.

Bishop, J.K.B., Collier, R.W., Ketten, D.R., Edmond, J.E., 1980. The chemistry, biology and vertical flux of particulate matter from the upper $1500 \mathrm{~m}$ of the Panama Basin. Deep-Sea Research 27A, 615-640.

Bochdansky, A.B., Herndl, G.J., 1992. Ecology of amorphous aggregations (marine snow) in the northern Adriatic Sea. III.
Zooplankton interactions with marine snow. Marine Ecology-Progress Series 87, 135-146.

Broecker, W.S., 1982. Ocean chemistry during glacial time. Geochimica Cosmochimica Acta 46, 1689-1705.

Buesseler, K.O., 1998. The decoupling of production and particulate export in the surface ocean. Global Biogeochemical Cycles 12, 297-310.

Cadee, G.C., 1985. Macroaggregates of Emiliani huxleyii in sediment traps. Marine Ecology-Progress Series 24, 193-196.

Calbet, A., Landry, M.R., 2004. Phytoplankton growth, microzooplankton grazing, and carbon cycling in marine systems. Limnology and Oceanography 49, 51-57.

Castberg, T., Larsen, A., Sandaa, R.A., Brussard, C.P., Egge, J.K., Heldal, M., Thyrhaug, R., vanHannen, E.J., Bratbak, G., 2001. Microbial population dynamics and diversity during a bloom of the marine coccolithophorid Emiliania huxleyii (Haptophyta). Marine Ecology — Progress Series 24, 39-46.

Chin, W.C., Orellana, M.V., Verdugo, P., 1998. Spontaneous assembly of marine dissolved organic matter into polymer gels. Nature 391, 568-572.

Cho, B.C., Azam, F., 1988. Major role of bacteria in biogeochemical fluxes in the ocean's interior. Nature 332, 441-443.

Dadou, I., Lamy, F., Rabouille, C., Ruiz-Pino, D., Andersen, V., Bianchi, M., Garçon, V., 2001. An integrated biological pump model from the euphotic zone to the sediment: a 1-D application in the Northeast tropical Atlantic. Deep-Sea Research II 48, 2345-2381.

De La Rocha, C.L., 2003. The biological pump. In: Elderfield, H. (Ed.), The Oceans and Marine Geochemistry, Vol. 6 Holland, H.D., Turekian, K.K. (Eds.), Treatise on Geochemistry. Elsevier-Pergammon, Oxford, pp. 83-111.

del Giorgio, P.A., Duarte, C.M., 2002. Respiration in the open ocean. Nature 420, 379-384.

Dilling, L., Alldredge, A.L., 2000. Fragmentation of marine snow by swimming macrozooplankton: a new process impacting carbon cycling in the sea. Deep-Sea Research I 47, 1227-1245.

Dilling, L., Wilson, J., Steinberg, D., Alldredge, A., 1998. Feeding by the euphausiid Euphausia pacifica and the copepod Calanus pacificus on marine snow. Marine Ecology-Progress Series 170, 189-201.

Doney, S.C., Kleypas, J.A., Sarmiento, J.L., Falkowski, P.G., 2002. The US JGOFS Synthesis and Modeling Project- an introduction. Deep-Sea Research II 49, 1-20.

Ducklow, H.W., 2000. Bacterial production and biomass in the oceans. In: Kirchman, D.L. (Ed.), Microbial Ecology of the Oceans. Wiley-Liss, New York, pp. 85-120.

Dymond, J., Collier, R., 1988. Biogenic particle fluxes in the equatorial Pacific: evidence for both high and low productivity during the 1982-1983 El Niño. Global Biogeochemical Cycles 2, 129-137.

Dymond, J., Lyle, M., 1982. Flux comparisons between sediments and sediment traps in the eastern tropical Pacific: implications for atmospheric $\mathrm{CO}_{2}$ variations during the Pleistocene. Limnology and Oceanography 30, 699-712.

Dymond, J., Lyle, M., 1994. Particle fluxes in the ocean and implications for sources and preservation of ocean sediments. In: Material Fluxes on the Surface of the Earth. National Academy Press, Washington, DC, pp. 125-142.

Engel, A., Delille, B., Jacquet, S., Riebesell, U., Rochelle-Newall, E., Terbruggen, A., 2004. Transparent exopolymer particles 
and dissolved organic carbon production by Emiliania huxleyi exposed to different $\mathrm{CO}_{2}$ concentrations: a mesocosm experiment. Aquatic Microbial Ecology 34, 93-104.

Field, C.B., Behrenfeld, M.J., Randerson, J.T., Falkowski, P., 1998. Primary production of the biosphere: integrating terrestrial and oceanic components. Science 281, 237-240.

Fischer, G., Wefer, G., 1996. Long-term observation of particle fluxes in the eastern Atlantic: seasonality, changes of flux with depth and comparison with the sediment record. In: Wefer, G., Berger, W.H., Siedler, G., Webb, D. (Eds.), The South Atlantic: Present and Past Circulation. Springer, Heidelberg, pp. 325-344.

Fischer, G., Fütterer, D., Gersonde, R., Honjo, S., Ostermann, D., Wefer, G., 1988. Seasonal variations of particle flux in the Weddell Sea and its relation to ice cover. Nature 335, 426-428.

Fischer, G., Neuer, S., Wefer, G., Krause, G., 1996. Short-term sedimentation pulses recorded with a fluorescence sensor and sediment traps at $900-\mathrm{m}$ depth in the Canary basin. Limnology and Oceanography 41, 1354-1359.

Fowler, S.W., Knauer, D.A., 1986. The role of large particles in the transport of elements and organic components through the ocean water column. Progress in Oceanography 16, 147-194.

François, R., Honjo, S., Krishfield, R., Manganini, S., 2002. Factors controlling the flux of organic carbon to the bathypelagic zone of the ocean. Global Biogeochemical Cycles 16.

Goldthwait, S., Yen, J., Brown, J., Alldredge, A., 2004. Quantification of marine snow fragmentation by swimming euphausiids. Limnology and Oceanography 49, 940-952.

Goldthwait, S., Carlson, C.A., Henderson, G.K., Alldredge, A.L., 2005. Effects of physical fragmentation on remineralization of marine snow. Marine Ecology-Progress Series 305, 59-65.

Gorsky, G., 2004. Vertical distribution of suspended aggregates at station EU52-Cam003. PANGAEA doi:10.1594/PANGAEA.140777.

Gorsky, G., Picheral, M., 2004a. Vertical distribution of suspended aggregates at station ANTARES-III_PAN09. PANGAEA doi:10.1594/PANGAEA.137207.

Gorsky, G., Picheral, M., 2004b. Vertical distribution of suspended aggregates at station EBENE_PVM30 (12 mm camera). PANGAEA doi:10.1594/PANGAËA.187982.

Gorsky, G., Chretiennot-Dinet, M.J., Blanchot, J., Palazzoli, I., 1999. Picoplankton and nanoplankton aggregation by appendicularians: fecal pellet contents of Megalocercus huxleyi in the Equatorial Pacific. Journal of Geophysical ResearchOceans 104, 3381-3390.

Gorsky, G., Le Borgne, R., Pcheral, M., Stemmann, L., 2003. Marine snow latitudinal distribution in the equatorial Pacific along $180^{\circ}$. Journal of Geophysical Research 108.

Graham, W.M., MacIntrye, S., Alldredge, A.L., 2000. Diel patterns in the concentration of marine snow and its implications for particle flux in surface waters. Deep-Sea Research I 47, 367-395.

Green, E.P., Dagg, M.J., 1997. Mesozooplankton associations with medium to large marine snow aggergates in the northern Gulf of Mexico. Journal of Plankton Research 19, 435-447.

Hamm, C.E., 2002. Interactive aggregation and sedimentation of diatoms and clay-sized lithogenic material. Limnology and Oceanography 47, 1790-1795.
Hansen, J.L.S., Kiørboe, T., Alldredge, A.L., 1996. Marine snow derived from abandoned larvacean houses: sinking rates, particle content, and mechanisms of aggregate formation. Marine Ecology-Progress Series 141, 205-215.

Hedges, J.I., Keil, R.G., 1995. Sedimentary organic matter preservation: an assessment and speculative analysis. Marine Chemistry 49, 81-115.

Hernández-León, S., Ikeda, T., 2005. A global assessment of mesozooplankton respiration in the ocean. Journal of Plankton Research 27, 153-158.

Hill, P., 1992. Reconciling aggregation theory with observed vertical fluxes following phytoplankton blooms. Journal of Geophysical Research 97, 2295-2308.

Hong, Y., Smith, W.O., White, A.-M., 1997. Studies on transparent exopolymer particles (TEP9 produced in the Ross Sea (Antarctica) and by Phaeocystis antarctica (Prymnesiophyceae). Journal of Phycology 33, 368-376.

Honjo, S., 1976. Coccoliths: production, transportation, sedimentation. Marine Micropaleontology 1, 65-79.

Honjo, S., 1982. Seasonality and interaction of biogenic and lithogenic particulate flux at the Panama Basin. Science 218, $883-884$.

Honjo, S., 1996. Fluxes of particles to the interior of the open oceans. In: Ittekkot, V., Schäfer, P., Honjo, S., Depetris, P.J. (Eds.), Particle Flux in the Ocean, SCOPE 57. Wiley, Chichester, pp. 91-154.

Honjo, S., Manganini, S.J., 1993. Annual biogenic particle fluxes to the interior of the North Atlantic Ocean: studied at $34^{\circ} \mathrm{N} 21^{\circ} \mathrm{W}$ and $48^{\circ} \mathrm{N} 21^{\circ} \mathrm{W}$. Deep-Sea Research II 40, 587-607.

Honjo, S., Roman, M.R., 1978. Marine copepod fecal pellets: production, preservation, and sedimentation. Journal of Marine Research 36, 45-57.

Honjo, S., Manganini, S.J., Cole, J.J., 1982. Sedimentation of biogenic matter in the deep ocean. Deep-Sea Research 29, 609-625.

Honjo, S., Doherty, A.L., Agrawal, Y.C., Asper, V.L., 1984. Direct optical assessment of large amorphous aggregates (marine snow) in the deep ocean. Deep-Sea Research 31, $67-76$.

Honjo, S., Dymond, J., Collier, R., Manganini, S.J., 1995. Export production of particles to the interior of the equatorial Pacific Ocean during the 1992 EqPac experiment. Deep-Sea Research II $42,831-870$.

Ingalls, A.E., Lee, C., Wakeham, S.G., Hedges, J.I., 2003. The role of biominerals in the sinking flux and preservation of amino acids in the Southern Ocean along $170^{\circ} \mathrm{W}$. Deep-Sea Research II 50, 713-738.

Jackson, G.A., 1990. A model of the formation of marine algal flocks by physical coagulation processes. Deep-Sea Research I 37, 1197-1211.

Jackson, G.A., Burd, A.B., 1998. Aggregation in the marine environment. Environmental Science and Technology 32, 2805-2814.

Jackson, G.A., Maffione, R., Costello, D.K., Alldredge, A.L., Logan, B.E., Dam, H.G., 1997. Particle size spectra between $1 \mu \mathrm{m}$ and $1 \mathrm{~cm}$ at Monterey Bay determined using multiple instruments. Deep-Sea Research I 44, 1739-1767.

Jahnke, R.A., 1996. The global ocean flux of particulate organic carbon: areal distribution and magnitude. Global Biogeochemical Cycles 10, 71-88. 
Jiang, Q., Logan, B.E., 1991. Fractal dimensions of aggregates determined from steady state size distributions. Environmental Science and Technology 25, 2031-2038.

Johnson, C.P., Li, X., Logan, B.E., 1996. Settling velocities of fractal aggregates. Environmental Science and Technology 30, 1911-1918.

Karl, D.M., Knauer, G.A., Martin, J.H., 1988. Downward flux of particulate organic matter in the ocean: a particle decomposition paradox. Nature 332, 438-441.

Keil, R.G., Montlucon, D.B., Prahl, F.G., Hedges, J.I., 1994. Sorpative preservation of labile organic matter in marine sediments. Nature 370, 549-552.

Kemp, A.E.S., Picke, P., Pearce, R.B., Lange, C.B., 2000. The "Fall dump" - a new perspective on the role of a "shade flora" in the annual cycle of diatom production and export flux. Deep-Sea Research II 47, 2129-2154.

Kepkay, P.E., 1994. Particle aggregation and the biological reactivity of colloids. Marine Ecology_Progress Series 109, 293-304.

Kiørboe, T., Jackson, G.A., 2001. Marine snow, organic solute plumes, and optimal chemosensory behavior of bacteria. Limnology and Oceanography 46, 1309-1318.

Kiørboe, T., Thygesen, U.H., 2001. Fluid motion and solute distribution around sinking aggregates. 2. Implications for remote detection by colonizing zooplankters. Marine Ecology-Progress Series 211, 15-25.

Kiørboe, T., Lundsgaard, C., Olesen, M., Hansen, J.L.S., 1994. Aggregation and sedimentation processes during a spring phytoplankton bloom: a field experiment to test coagulation theory. Journal of Marine Research 52, 297-323.

Klaas, C., Archer, D.E., 2002. Association of sinking organic matter with various types of mineral ballast in the deep sea: implications for the rain ratio. Global Biogeochemical Cycles 16.

Kohfeld, K.E., Le Quéré, C., Harrison, S.P., Anderson, R.F., 2005. Role of marine biology in glacial-interglacial $\mathrm{CO}_{2}$ cycles. Science 308, 74-78.

Komar, P.D., Morse, A.P., Small, L.F., Fowler, S.W., 1981. An analysis of sinking rates of natural copepod and euphausiid fecal pellets. Limnology and Oceanography 26, 172-180.

Kosky, M., Kiørboe, T., Takahashi, K., 2005. Benthic life in the pelagic: aggregate encounter and degradation rates by pelagic harpacticoid copepods. Limnology and Oceanography 50, $1254-1263$.

Kriest, I., 2002. Different parameterizations of marine snow in a 1D-model and their influence on representation of marine snow, nitrogen budget and sedimentation. Deep-Sea Research I 49, 2133-2162.

Kriest, I., Evans, G.T., 1999. Representing phytoplankton aggregates in biogeochemical models. Deep-Sea Research I 46, 1841-1859.

Lampitt, R.S., Noji, T., Bodungen, B.V., 1991. What happens to zooplankton fecal pellets? Implications for material flux. Marine Biology 104, 15-23.

Lampitt, R.S., Bett, B.J., Kiriakoulakis, K., Popova, E.E., Ragueneau, O., Vangriesheim, A., Wolff, G.A., 2001. Material supply to the abyssal seafloor in the Northeast Atlantic. Progress in Oceanography 50, 27-63.

Legendre, L., Michaud, J., 1998. Flux of biogenic carbon in oceans: size-dependent regulation by pelagic food webs. Marine Ecology_-Progress Series 164, 1-11.
Legendre, L., Rivkin, R., 2002. Fluxes of carbon in the upper ocean: regulation by food-web control nodes. Marine Ecology 242, 95-109.

Li, X., Logan, B.E., 1995. Size distribution and fractal properties of particles during a simulated phytoplankton bloom in a mesocosm. Deep-Sea Research II 42, 125-138.

Logan, B.E., Wilkinson, D.B., 1990. Fractal geometry of marine snow and other biological aggregates. Limnology and Oceanography 35, 130-136.

Logan, B.E., Passow, U., Alldredge, A.L., Grossart, H.-P., Simon, M., 1995. Rapid formation and sedimentation of large aggregates is predictable from coagulation rates (half-lives) of transparent exopolymer particles (TEP). Deep-Sea Research II 42, 203-214.

Lutz, M., Dunbar, R., Caldiera, K., 2002. Regional variability in the vertical flux of particulate organic carbon in the ocean interior. Global Biogeochemical Cycles 16.

Martin, J.H., Knauer, G.A., Karl, D.M., Broenkow, W.W., 1987. VERTEX: carbon cycling in the northeast Pacific. Deep-Sea Research 43, 267-285.

McCave, I.N., 1975. Vertical flux of particles in the ocean. DeepSea Research 22, 491-502.

McCave, I.N., 1984. Size spectra and aggregation of suspended particles in the deep ocean. Deep-Sea Research 31, 329-352.

MacIntyre, S., Alldredge, A.L., Gotschalk, C.C., 1995. Accumulation of marine snow at density discontinuities in the water column. Limnology and Oceanography 40, 449-468.

Martinez, J., Smith, D.C., Steward, G.F., Azam, F., 1996. Variability in ectohydrolytic enzyme activities of pelagic marine bacteria and its significance for substrate processing in the sea. Aquatic Microbial Ecology 10, 223-230.

Milliman, J.D., 1993. Production and accumulation of calcium carbonate in the ocean: budget of a non-steady state. Global Biogeochemical Cycles 7, 927-957.

Moulin, V., Moulin, C., 2001. Radionuclide speciation in the environment: a review. Radiochimica Acta 89, 773-778.

Moulin, V., Amekraz, B., Barre, N., Planque, G., Mercier, F., Reiller, P., Moulin, C., 2004. The role of humic substances in trace element mobility in natural environments and applications to radionuclides. In: Ghabbour, E., Davies, G. (Eds.), Humic Substances. Nature's Most Versatile Materials. Taylor and Francis Inc., New York, pp. 275-286.

Nejstgaard, J.C., Gismervik, I., Solberg, P.T., 1997. Feeding and reproduction by Calanus finmarchicus, and microzooplankton grazing during mesocosm blooms of diatoms and the coccolithophore, Emiliania huxleyii. Marine EcologyProgress Series 147, 197-217.

Nelson, D.M., Tréguer, P., Brzezinski, M.A., Leynaert, A., Quéguiner, B., 1995. Production and dissolution of biogenic silica in the ocean: revised global estimates, comparison with regional data, and relationship to biogenic silica sedimentation. Global Biogeochemical Cycles 9, 359-372.

Neuer, S., Davenport, R., Freudenthal, T., Wefer, G., Llinás, O., Rueda, M.-J., Steinberg, D.K., Karl, D.M., 2002. Differences in the biological carbon pump at three subtropical ocean sites. Geophysical Research Letters 29.

Noji, T.T., Estep, K.W., MacIntyre, F., Norrbin, F., 1991. Image analysis of faecal material grazed upon by three species of copepods: evidence for coprorhexy, coprophagy and coprochaly. Journal of Marine Biological Association of the United Kingdom 71, 465-480. 
Noji, T.T., Børsheim, K.Y., Rey, F., Nortvedt, R., 1999. Dissolved organic carbon associated with sinking particles can be crucial for estimates of vertical carbon flux. Sarsia 84, $129-135$.

Passow, U., 2002. Transparent exopolymer particles (TEP) in aquatic environments. Progress in Oceanography 55, 287-333.

Passow, U., 2004. Switching perspectives: do mineral fluxes determine particulate organic carbon fluxes or vice versa? Geochemistry Geophysics Geosystems 5.

Passow, U., De La Rocha, C.L., 2006. The accumulation of mineral ballast on organic aggregates. Global Biogeochemical Cycles, 210.1029/2005GB002579.

Passow, U., Wassmann, P., 1994. On the trophic fate of Phaeocystis pouchetii (Hariot): IV. The formation of marine snow by P. pouchetii. Marine Ecology_Progress Series 104, 151-163.

Passow, U., Alldredge, A.L., Logan, B.E., 1994. The role of particulate carbohydrate exudates in the flocculation of diatom blooms. Deep-Sea Research I 41, 335-357.

Pilskaln, C.H., Honjo, S., 1987. The fecal pellet fraction of biogeochemical particles fluxes to the deep sea. Global Biogeochemical Cycles 1, 31-48.

Pilskaln, C.H., Lehmann, C., Paduan, J.B., Silver, M.W., 1998. Spatial and temporal dynamics in marine aggregate abundance, sinking rate and flux: Monterey Bay, central California. Deep-Sea Research II 45, 1803-1837.

Ploug, H., Hietanen, S., Kuparinen, J., 2002. Diffusion and advection within and around sinking, porous diatom aggregates. Limnology and Oceanography 47, 1129-1136.

Ragueneau, O., Tréguer, P., Leynaert, A., Anderson, R.F., Brzezinski, M.A., DeMaster, D.J., Dugdale, R.C., Dymond, J., Fischer, G., François, R., Heinze, C., Maier-Reimer, E., Martin-Jézéquel, V., Nelson, D.M., Quéguiner, B., 2000. A review of the $\mathrm{Si}$ cycle in the modern ocean: recent progress and missing gaps in the application of biogenic opal as a paleoproductivity proxy. Global Planetary Change 26, 317-365.

Ragueneau, O., Gallinari, M., Corrin, L., Grandel, S., Hall, P., Hauvespre, A., Lampitt, RS., Rickert, D., Stahl, H., Tengberg, A., Witbaard, R., 2001. The benthic silica cycle in the Northeast Atlantic: annual mass balance, seasonality, and importance of non-steady-state processes for the early diagenesis of biogenic opal in deep-sea sediments. Progress in Oceanography 50, 171-200.

Riebesell, U., 1991. Particle aggregation during a diatom bloom. II. Biological aspects. Marine Ecology—Progress Series 69, 281-291.

Riebesell, U., Reigstad, M., Wassmann, P., Noji, T., Passow, U., 1995. On the trophic fate of Phaeocystis pouchetii (Hariot): VI. Significance of Phaeocystis-derived mucus for vertical flux. Netherlands Journal of Sea Research 33, 193-203.

Rieman, F., 1989. Gelatinous phytoplankton detritus aggregates on the Atlantic deep-sea bed structure and mode of formation. Marine Biology 100, 533-539.

Rivkin, R.B., Legendre, L., 2001. Biogenic carbon cycling in the upper ocean: effects of microbial respiration. Science 291, 2398-2400

Roth, S.E., Dymond, J., 1989. Transport and settling of organic material in a deep-sea hydrothermal plume: evidence from particle flux measurements. Deep-Sea Research 36, $1237-1254$.
Schiebel, R., 2002. Planktic foraminiferal sedimentation and the marine calcite budget. Global Biogeochemical Cycles 16.

Schlitzer, R., 2000. Applying the adjoint method for biogeochemical modeling: export of particulate organic matter in the world ocean. In: Kasibhata, P. (Ed.), Inverse Methods in Global biogeochemical Cycles, AGU Monograph, No. 114. American Geophysical Union, Washington, DC, pp. 107-124.

Schnetzer, A., Steinberg, D.K., 2002. Natural diets of vertically migrating zooplankton in the Sargasso Sea. Marine Biology 141, 89-99.

Sempéré, R., Yoro, S.C., Van Wambeke, F., Charriere, B., 2000. Microbial decomposition of large organic particles in the northwestern Mediterranean Sea: an experimental approach. Marine Ecology_-Progress Series 198, 61-72.

Shanks, A.L., Trent, J.D., 1980. Marine snow: sinking rates and potential role in vertical flux. Deep-Sea Research 27A, $137-143$.

Sies, H., 1988. A new parameter for sex education. Nature 332, 495.

Sigman, D.M., Boyle, E.A., 2000. Glacial/interglacial variations in atmospheric carbon dioxide. Nature 407, 859-869.

Silver, M.W., Gowing, M.M., 1991. The "particle" flux: origins and biological components. Progress in Oceanography 26, $75-113$.

Simon, M., Grossart, H.-P., Schweitzer, B., Ploug, H., 2002. Microbial ecology of organic aggregates in aquatic ecosystems. Aquatic Microbial Ecology 28, 175-211.

Small, L.F., Fowler, S.W., Unlu, M.Y., 1979. Sinking rates of natural copepod fecal pellets. Marine Biology 51, 233-241.

Smayda, T.J., 1970. The suspension and sinking of phytoplankton in the sea. Oceanography and Marine Biology-An Annual Review 8, 353-414.

Smetacek, V., 1985. Role of sinking in diatom life-history cycles: ecological, evolutionary, and geological significance. Marine Biology 84, 239-251.

Smith, D.C., Simon, M., Alldredge, A.L., Azam, F., 1992. Intense hydrolitic enzyme activity on marine aggregates and implications for rapid particle dissolution. Nature 359, 139-141.

Steinberg, D.K., Carlson, C.A., Bates, N.R., Goldthwait, S.A., Madin, L.P., Michaels, A.F., 2000. Zooplankton vertical migration and the active transport of dissolved organic and inorganic carbon in the Sargasso Sea. Deep-Sea Research I 47, 2000

Stemmann, L., Jackson, G.A., Ianson, D., 2004a. A vertical model of particle size distributions and fluxes in the midwater column that includes biological and physical processes- part I: model formulation. Deep-Sea Research I 51, 865-884.

Stemmann, L., Jackson, G.A., Gorsky, G., 2004b. A vertical model of particle size distributions and fluxes in the midwater column that includes biological and physical processes- part II: application to a three year survey in the NW Mediterranean Sea. Deep-Sea Research I 51, 885-908.

Suess, E., 1980. Particulate organic carbon flux in the oceanssurface productivity and oxygen utilization. Nature 288, 260-263.

Thibault, D., Roy, S., Wong, W.S., Bishop, J.K., 1999. The downward flux of biogenic materials in the NE subarctic Pacific: importance of algal sinking and mesozooplankton herbivory. Deep-Sea Research II 46, 2669-2697.

Thor, P., Dam, H.G., Rogers, D.R., 2003. Fate of organic carbon released from decomposing copepod fecal pellets in relation to 
bacterial production and ectoenzymatic activity. Aquatic Microbial Ecology 33, 279-288.

Thornton, D.C.O., 2002. Diatom aggregation in the sea: mechanisms and ecological implications. European Journal of Phycology 37, 149-161.

Tietjen, T., Wetzel, R.G., 2003. Extracelular enzyme-clay mineral complexes: enzyme adsorption, alteration of enzyme activity, and protection from photodegradation. Aquatic Ecology 37, 331-339.

Turner, J.T., 2002. Zooplankton fecal pellets, marine snow and sinking phytoplankton blooms. Aquatic Microbial Ecology 27, 57-102.

Verdugo, P., Alldredge, A.L., Azam, F., Kirchman, D.L., Passow, U., Santschi, P.H., 2004. The oceanic gel phase: a bridge in the DOM-POM continuum. Marine Chemistry 92, 67-85.

Volkman, J.K., Tanoue, E., 2002. Chemical and biological studies of particulate organic matter in the ocean. Journal of Oceanography 58, 265-279.

Von Bodungen, B., Antia, A., Bauerfeind, E., Haupt, O., Peeken, I., Peinert, R., Reitmeier, S., Thomsen, C., Voss, M., Wunsch, M., Zeller, U., Zeitschel, B., 1995. Pelagic processes and vertical flux of particles: an overview of a long-term comparative study in the Norwegian Sea and Greenland Sea. Geologishe Rundschau 84, 11-27.
Wassmann, P., 1998. Retention versus export food chains: processes controlling sinking loss from marine pelagic systems. Hydrobiologia 363, 29-57.

Wassmann, P., Ypma, J.E., Tselepides, A., 2000. Vertical flux of faecal pellets and microplankton on the shelf of the oligotrophic Cretan Sea (NE Mediterranean Sea). Progress in Oceanography 46, 241-258.

Wefer, G., Fischer, G., 1991. Annual primary production and export flux in the Southern Ocean from sediment trap data. Marine Chemistry 35, 597-613.

Wefer, G., Fischer, G., 1993. Seasonal patterns of vertical particle flux in equatorial and coastal upwelling areas of the eastern Atlantic. Deep-Sea Research I 40, 1613-1645.

Wefer, G., Fischer, G., Fütterer, D., Gersonde, R., 1988. Seasonal particle flux in the Bransfield Strait, Antarctica. Deep-Sea Research 35, 891-898.

Wong, C.S., Whitney, F.A., Crawford, D.W., Iseki, K., Matear, R.J., Johnson, W.K., Page, J.S., 1999. Seasonal and interannual variability in particle fluxes of carbon, nitrogen, and silicon from times series of sediment traps at Ocean Station P, 1982-1993: relationship to changes in subarctic primary productivity. Deep-Sea Research II 46, $2735-2760$. 